\title{
Cancer, Quackery and the Vernacular Meanings of Hope in I950s America
}

\author{
DAVID CANTOR *
}

ABSTRACT. Hope was central to cancer control in twentieth-century America. Physicians placed great store in its power to persuade people to seek medical help as early as possible in the development of the disease, when it was most amenable to treatment; to maintain patients' loyalty through what could be a long, painful and uncertain course of therapy; and to encourage doubts about alternative healers. Some also argued that hope could have beneficial therapeutic and psychological effects for patients. However, we know very little about its meanings for the public. Focusing on a large collection of letters written to the Food and Drug Administration in the I950s concerning an anti-quackery campaign, this article explores how men and women responded to the competing messages of hope promoted by orthodox cancer organizations and by alternative healers. It asks: What did hope mean to such men and women? How did they construct this meaning? How did they decide which treatments were hopeful and which were not? And, how did they use hope to imagine the social world of cancer? In short, this article explores the vernacular meanings, epistemologies, and imaginative uses of hope among Americans in the mid-twentieth century. KEYWORDs: hope, cancer, quackery, Harry M. Hoxsey, Food and Drug Administration.

\footnotetext{
* David Cantor, Division of Cancer Prevention, National Cancer Institute, Executive Plaza North, Suite 2025, Bethesda, MD 20892-7309. Email: cantord@mail.nih.gov. This article would have been impossible without the help of John Swann and Suzanne Junod (FDA) and Robert Tenuta and Laura Carroll (AMA), who provided me with access to their respective archival collections. I owe a particular debt to John Swann, who brought the FDA collection to my notice, explained the sometimes arcane workings of that agency, and introduced me to stir-fry Fridays in the FDA canteen, now sadly discontinued. The research for this article was supported by the Division of Cancer Prevention (DCP), National Cancer Institute (PO: 263-MQ-2 I6827). Earlier versions were presented to the Biomedical Research History Interest Group at the National Institutes of Health, I4 January 2003; at the Divinity School, Vanderbilt University, 3 April 2003; and at the workshop "Patients and Pathways. Cancer Therapies in Historical and Sociological Perspective," held at the Centre for the History of Science, Technology and Medicine, University of Manchester, 6-8 October 2005.

JOURNAL OF THE HISTORY OF MEDiCINE AND ALLIED SCIENCES, Volume 6i, Number 3

(C) The Author 2006. Published by Oxford University Press. All rights reserved.

For permissions, please e-mail: journals.permissions@oxfordjournals.org

Advance Access publication on March 24, 2006

doi:Io. I093/jhmas/jrjo48
} 

his major work on cancer, You Don't Have to Die, he took a very dim view of the response of most physicians to the disease. Doctors, he claimed, were infected by panic. They had little confidence in the treatments they prescribed. Experience had taught them that a cancer patient was unlikely to survive long. The average physician, he noted, had "given up hope, [and had] mentally consigned the helpless wretch [the patient] to death," and the patient would generally oblige by dying on time. ${ }^{1}$ In Hoxsey's view, the tragedy was that these deaths were quite preventable. "No case of cancer, however far advanced, is entirely hopeless," he claimed. ${ }^{2}$ The problem was not the disease, but the physician's attitude: his hopelessness was "contagious," and patients who caught the contagion gave up and died. Part of the aim of You Don't Have to Die was to instill in the public a hope that cancer could be cured.

Hoxsey was not alone in encouraging such hope. Thus, shortly after its foundation in I9I3, the American Society for the Control of Cancer (ASCC) instituted what it called a "Message of Hope" in its efforts to persuade Americans to seek early diagnosis and treatment. ${ }^{3}$ The "message" - that cancer was curable if caught early and treated by a recognized physician-was adopted by virtually all other American cancer organizations and came to be a central part of cancer control policies during the first half of the century. ${ }^{4}$ Most important for my purposes, the "message of hope" came to play a significant symbolic role as a counterweight to the

I. Harry M. Hoxsey, You Don't Have to Die (New York: Milestone Books, I956), 7.

2. Ibid.

3. James T. Patterson, The Dread Disease. Cancer and Modern American Culture (Cambridge, Mass., and London: Harvard University Press, I987), 76. Metropolitan Life Insurance Company in Collaboration with the ASCC, A Message of Hope About Cancer, n.d. (in press in I94I), copy available in American Society for the Control of Cancer, New York, Catalog of Educational Material (New York: ASCC, I94I-44), available at the National Library of Medicine (hereafter NLM), Bethesda, Md., call number QZ 200 A5I8c I94I. On early diagnosis and treatment, see R. A. Aronowitz, "Do Not Delay: Breast Cancer and Time, I900-I970," Milbank Q., 200I, 79, 355-86.

4. On the history of cancer control, see Lester Breslow et al., A History of Cancer Control in the United States, with Emphasis on the Period 1946-1971, prepared by the History of Cancer Control Project, UCLA School of Public Health, pursuant to Contract no. No ICN-55I72 (Division of Cancer Control and Rehabilitation, National Cancer Institute, Bethesda, Md.: Dept. of Health, Education, and Welfare, Public Health Service, National Institutes of Health, National Cancer Institute, Division of Cancer Control and Rehabilitation, I977). 
pervasive image of cancer as a "hopeless" or incurable condition. ${ }^{5}$ Without hope of a cure, these organizers suggested, it would be difficult to persuade sufferers to seek early diagnosis and treatment. It would also be difficult to sustain what would come to be known as patient compliance. ${ }^{6}$ And it would also be hard to stop patients from drifting into the arms of "quacks" and purveyors of patent medicines. Cancer agencies recognized (long before Hoxsey) that physicians themselves often regarded the disease as a hopeless condition, thus undermining public faith in cancer control and opening the door to alternative healers. Physicians were consequently urged to emphasize the hopeful side of the disease in their dealings with the lay public. As a I944 manual for physicians noted: "In all lay talks on cancer the optimistic, hopeful side of the problem should be kept before the audience."7

But if Hoxsey and the cancer agencies agreed that hope was crucial to cancer control, that was about all that they agreed on. Hoxsey, one of the most successful alternative practitioners of the I950s, argued that the only hope of a cure for cancer was his own treatment for the disease. Regular physicians, he claimed, not only regarded the disease as "hopeless," they actually had no hope to offer: orthodox treatments for cancer-surgery, X rays, and radium-did not cure the disease. The "message of hope" put out by the cancer agencies, he claimed, was little more than a fraud-a claim that cancer agencies vigorously opposed. From their perspective, Hoxsey's claims were little more than an effort to drum up custom for his own (and to

5. Historical work on hope includes Patterson, Dread Disease, 76; Barron H. Lerner, The Breast Cancer Wars. Hope, Fear, and the Pursuit of a Cure in Twentieth-Century America (New York: Oxford University Press, 200I), esp. 31, 272-73; David Cantor, "Radium, Cancer and the Meanings of Hope in Early Twentieth Century American Medicine," manuscript in preparation. The discourse of hope has also become an important focus of sociological and anthropological study. See Mary-Jo DelVecchio Good, Byron J. Good, Cynthia Schaffer, and Stuart E. Lind, "American Oncology and the Discourse of Hope," Cult. Med. Psychiatry, I990, 14, 59-79; Mary-Jo DelVecchio Good, "The Practice of Biomedicine and the Discourse on Hope: A Preliminary Investigation into the Culture of American Oncology," in Beatrix Pfleiderer and Gilles Bibeau, Anthropologies of Medicine: A Colloquium on Western European and North American Perspectives (Heidelberg, Germany: Vieweg, I99I), special issue of Curare, I99I, 7, I2 I-35; M. J. DelVecchio Good, T. Munakata, Y. Kobayashi, C. Mattingly, and B. Good, "Oncology and Narrative Time," Soc. Sci. Med., I994, 38, 855-62. See also Mary-Jo DelVecchio Good, American Medicine: The Quest for Competence (Berkeley, Los Angeles, and London: University of California Press, I998), esp. Part III.

6. Jeremy A. Greene, “Therapeutic Infidelities: 'Noncompliance' enters the Medical Literature, I955-1975," Soc. Hist. Med., 2004, 17, 327-43.

7. Michigan State Medical Society and Michigan Department of Health, Cancer: A Manual for Physicians ([Lansing]: Jointly by Michigan State Medical Society and Michigan Department of Health, I944), 22 I. 
them dubious) methods. Whereas Hoxsey portrayed himself as the "only hope" for those with cancer, orthodox cancer agencies argued that what he in fact offered was the "false hope" of a cure for the disease. And where Hoxsey argued that surgery, $\mathrm{X}$ rays, and radium offered little or no hope of a cure, the cancer agencies argued that these three modalities were in fact the only hope for a cure. Hope thus came to play a central political role in the struggle between the two sides. Both placed great store in its power to attract patients to their respective treatment regimens, to maintain patient loyalty through the vicissitudes of therapy, to sustain trust in their expertise, and to encourage doubts about the opposition. This article explores the public's responses to the competing messages of hope put out by Hoxsey and his opponents and what they tell us about the vernacular meanings and uses of hope in I950s America.

My focus is a collection of several thousand letters written to the Food and Drug Administration (FDA) in the mid- to late I950s (especially I956-I957) concerning a campaign the agency launched against Hoxsey. ${ }^{8}$ As the federal body concerned with regulating drugs, the FDA had taken a growing interest in Hoxsey's medications for cancer from the late I940s. ${ }^{9}$ But its efforts to stop his activities were largely frustrated, and Hoxsey's popularity seemed to grow. Thus, in April I956, the agency issued a public warning to the nation, urging people not to go to Hoxsey and inviting them to write for further information (see Figure I).

Thousands responded to the invitation. Most were simple requests for the more information that the FDA promised. But a

8. In addition to these letters (available through Food and Drug Administration's [FDA] History Office HFC-24, Room I2-69, 5600 Fishers Lane, Rockville, MD 20857 [hereafter FDA archives]), a small number of letters concerning Hoxsey can also be found in the AMA's health fraud collection, held at American Medical Association, Department of Archives, 5I5 North State Street, Chicago, IL 606Io (hereafter AMA archives). Access to the FDA collection was conditional upon maintaining the anonymity of correspondents, other than government officials, physicians, and scientists. Therefore, most correspondents are identified only by their initials and the town and state from which the letter originated. James T. Patterson refers to a collection of letters about Hoxsey preserved at the NCI and scheduled for transfer to the National Archives in I986. I have been unable to locate these letters. Patterson, Dread Disease, I63 and $32 \mathrm{I}$.

9. For histories of the FDA, see Philip J. Hilts, Protecting America's Health: The FDA, Business, and One Hundred Years of Regulation (New York: Alfred A. Knopf, 2003); Charles O. Jackson, Food and Drug Legislation in the New Deal (Princeton, N.J.: Princeton University Press, 1970); John P. Swann, "Food and Drug Administration," in George Thomas Kurian, ed., A Historical Guide to the U. S. Government (New York: Oxford University Press, I998), 248-54. 


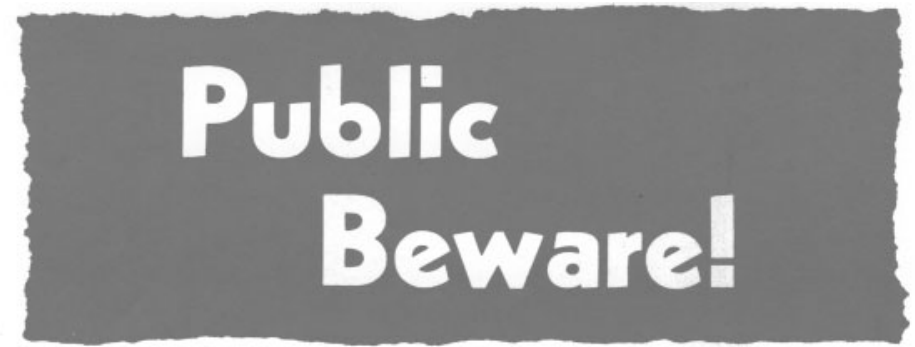

\section{WARNING AGAINST THE HOXSEY CANCER TREATMENT}

Sufferers from cancer, their families, physicians, and all concerned with the care of cancer patients are hereby advised and warned that the Hoxsey treatment for internal cancer has been found worthless by two Federal courts.

The Hoxsey treatment costs $\$ 400$, plus $\$ 60$ in additional fees_-expenditures which will yield nothing of value in the care of cancer. It consists essentially of simple drugs which are worthless for treating cancer.

The Food and Drug Administration conducted a thorough investigation of the Hoxsey treatment and the cases which were claimed to be cured. Not a single verified cure of internal cancer by this treatment has been found.

Those afflicted with cancer are warned not to be misled by the false promise that the Hoxsey cancer treatment will cure or alleviate their condition. Cancer can be cured only through surgery or radiation. Death from cancer is inevitable when cancer patients fail to obtain proper medical treatment because of the lure of a painless cure "without the use of surgery, x-ray, or radium" as claimed by Hoxsey.

Anyone planning to try this treatment should get the facts about it.

$$
\begin{aligned}
& \text { For further information mrite to: } \\
& \text { U. S. DEPARTMENT OF HEALTH, EDUCATION, AND WELFARE } \\
& \text { Food and Dreg Administration } \\
& \text { Washington 25, D. C. }
\end{aligned}
$$

Fig. I. The FDA campaign against Hoxsey included placing "Public Beware" posters in 46,000 post offices and postal substations across the country. Courtesy of the Federal Drug Administration, History Office.

substantial number took the opportunity to write more. In so doing they set out what they meant by hope, how they chose between the competing messages of hope provided by Hoxsey and his critics, and how they assessed what was hopeful and what was not. They also 
used hope to write about the social world of cancer. Thus these letters provide a window onto the vernacular meanings, epistemologies, and imaginative uses of hope. The historiographic intent of this article is to recover these meanings and uses.

\section{HOXSEY, THE FDA AND THE ORIGINS OF THE LETTERS}

Born in I90I, the youngest of twelve children, Harry Hoxsey grew up in Girard, a small town southwest of Springfield in rural Illinois. ${ }^{10}$ Leaving school after the eighth grade, he worked in the coal mines of nearby Taylorville and sold insurance on the side. He started treating cancer around I920 or I92 I, employing an escharotic paste, a corrosive chemical (apparently discovered by his father or great-grandfather) that ate away the flesh. ${ }^{11}$ His practice flourished. In I924 he opened cancer clinics in Taylorville and (briefly) Chicago, and in I925 he established the Hoxide Institute under the sponsorship of the Taylorville Chamber of Commerce. The Illinois attorney's office pressed charges against him for practicing medicine without a license, and this - and the fact that in I927 other members of his family sued him for a share of their father's estate- led to the closure of the Institute in I928. For the next few years Hoxsey lived an itinerant existence, continuing to treat patients at various locations, mainly in the Midwest, the East, and the South, during which time he also qualified as a naturopath. In I936 he set up a clinic in Dallas, Texas, and broadened the range of therapies available. Now he also offered an internal-what he called "chemotherapeutic"12 medication for cancer, initially dispensed as a liquid and later given

Io. The details of Hoxsey's career and life are taken from the AMA's Health Fraud Collection; James Harvey Young, The Medical Messiahs: A Social History of Health Quackery in Twentieth-Century America (Princeton, N.J.: Princeton University Press, I967), 360-89; Kenny Ausubel, When Healing Becomes a Crime: The Amazing Story of the Hoxsey Cancer Clinics and the Return of Alternative Therapies (Rochester, Vt.: Healing Arts Press, 2000); and Eric S. Juhnke, Quacks and Crusaders: The Fabulous Careers of John Brinkley, Norman Baker, and Harry Hoxsey (Lawrence: University Press of Kansas, 2002).

I I. Many commentators suggest that Hoxsey began treating in I922. Hoxsey's own testimony is that he started in I920 or I92I. I920, "Examination before Trial of Plaintiff: Harry M. Hoxsey," in United States District Court, Southern District of New York, Harry M. Hoxsey vs. Newspaper PM Inc. \& Albert Deutsch, 39, ca. I947, Box 0376 File 07, Health Fraud Collection, AMA archives. I92 I, "Testimony of Harry M. Hoxsey," in A. M. Richards vs. Harry M. Hoxsey in District Court, Dallas County, Texas, 44th Judicial District, $5 \mathrm{I}$, ca. I948, Box 0376, File I I, Health Fraud Collection, AMA archives.

I2. Some patients echoed this language of chemotherapy. See EJS [Northville, Michigan] to FDA, I I February I957, Accession 63A292, Box 529, Folder 48, FDA archives. WAH [Ada, Oklahoma] to J. L. Harvey, I5 April I957, Accession 63A292, Box 529, Folder 54, FDA archives. 
in pill form. His practice expanded, and in I946 Hoxsey opened a new, enlarged clinic in Dallas, the center of his operations until it closed in the early I960s. By the I950s, this clinic was one of the largest cancer treatment centers-orthodox or otherwise-in the country. Other Hoxsey clinics were springing up, including, in I955, one at Portage in Pennsylvania that closed almost the moment it opened, following a widely publicized raid by FDA agents and subsequent litigation. Hoxsey also routinely treated people by mail, shipping his remedies to patients across the country. According to one estimate, Hoxsey's gross annual income in the mid-I950s was around $\$$ I.5 million from some 8000 patients. ${ }^{13}$

Orthodox physicians regarded Hoxsey as a smooth-talking salesman, a "fake," "fraud," or "fakir" who fed off the hopes of those with cancer. As Oliver Field, the director of the American Medical Association's (AMA) Bureau of Investigation, put it, Hoxsey boasted that he rode around "in an air-conditioned Cadillac, and his money for such is obtained from hopeful cancer victims." ${ }^{14}$ For his part, Hoxsey portrayed himself as the defender of the small man, a patriot, anti-communist, Christian, and an untiring crusader for the sick and the vulnerable. ${ }^{15}$ His healing power was a gift from God, he claimed. Yet, like Jesus Christ, he also saw himself as persecuted for trying to help the needy. "Why these quacks insist on mixing religion with their mischief is difficult for me to understand," Field noted, "except that it demonstrates the essential fraudulence of the manner in which they parade around pretending to have concern for man's spiritual welfare."'

Medical organizations were worried about not only Hoxsey's message, but also his ability to disseminate it. Hoxsey was a gifted speaker, appearing regularly on the radio and in other public speaking forums. He published books and tracts on his treatment and attracted considerable attention from the religious and alternative

I3. Young, Medical Messiahs, 380. For other evidence of Hoxsey's growing popularity in the I950s, see Report of a Committee of Faculty Members of the University of British Columbia Concerning the Hoxsey Treatment for Cancer, 1957, I4. Copy in NLM, call number W6 P 3 v.64I5.

I4. Oliver Field to Rev. Lloyd C. Shank, 22 July I955, Box 0368, File 02, Health Fraud Collection, AMA archives.

I5. Patterson, Dread Disease, i63.

I6. Ibid., I08. One correspondent took up the theme, warning the FDA that those who "persecuted" Hoxsey faced eternal punishment. MB [Seguin, Texas] to FDA, 25 February I957, Accession 63A292, Box 529, Folder 48, FDA archives.

I7. Oliver Field to Delos Smith (Science Editor, United Press Associations, NY), 23 April i954, Box 0367, File 05, Health Fraud Collection, AMA archives. 
health press. Sympathetic reports in Man's Magazine ${ }^{18}$ and the Catholic magazine Scarboro Missions ${ }^{19}$ aroused AMA concern. But most attention focused on a slew of articles in The Defender Magazine, published by the right-wing evangelical fundamentalist Gerald Winrod, "the rabblerousing publisher-preacher-radio orator of Wichita, Kan.," as Field described him. ${ }^{20}$ Such publications reached an audience that cancer control organizations found difficult to appeal to, and their anxieties were exacerbated by Hoxsey's ability to attract political, medical, and financial support for his operations. For example, the Portage clinic was established with the support of state senator John Haluska, and in Dallas, Hoxsey appears to have fallen in with right-wing conservatives such as the millionaire H. L. Hunt. ${ }^{21}$ As one AMA critic put it in the I930s: "The trouble is that Hoxsey has been able to interest some wealthy men in his rotten scheme, and when money begins to talk, it usually makes a noise."22

In their efforts to dissuade people from attending his clinic, the AMA and allied opponents of Hoxsey routinely questioned his claims to offer hope for cancer. For example, the FDA repeatedly warned (potential) Hoxsey clients that he offered "no hope," ${ }^{23}$ or

I8. Allen Bernard, “Man's Magazine Investigates a Cure for Cancer," Man's Mag., August I953, 1, IO-I4, 56-58. Bernard noted (I2) that many of Hoxsey's supporters told of "how their own physicians gave them up as 'hopeless' and sent them home to die, how as a last resort they came to Hoxsey for treatment." See also Allen Bernard, "I Conquered Cancer!"," Man's Mag., August I954, 2, I3-17, 72-80; Editorial, "Man's Corner," Man's Mag., August I954, 2, 4, 80.

I9. William C. McGrath, S. F. M., P. A. "From the Crow's Nest," reprint from Scarboro Missions, December 1955, Accession 63A292, Box 526, Folder I I, FDA archives. McGrath noted of the Portage Clinic, "this is a story of hope . . . You could see and feel that hope, in the eyes of the patients who lined the reception rooms. You could hear it from the lips of victim after victim, sent home to die before then heard of a man named Hoxsey."

20. Oliver Field to Delos Smith (Science Editor, United Press Associations, NY), 23 April I954, Box 0367, File 05, Health Fraud Collection, AMA archives. On Winrod, see Gail Anne Sindell, "Gerald B. Winrod and the Defender: A Case Study of the Radical Right" (Ph.D. diss., Case Western Reserve University, I973).

2 I. Young, Medical Messiahs, 384-86. Juhnke, Quacks and Crusaders, 77, 86-87, I 36-42. For Hoxsey's right-wing connections, see also Sindell, "Gerald B. Winrod and the Defender."

22. Dr. Arthur J. Cramp to Joseph Colt Bloodgood, 23 February I933, Box 0366, File 08, Health Fraud Collection, AMA archives.

23. "The Hoxsey treatment offers her [your mother] no hope whatsoever and, as you know, delay is cancer's greatest ally." K. L. Milstead to JE [Okmulgee, Oklahoma], 6 August I956, Accession 63A292, Box 526, Folder I 5, FDA archives. "The Hoxsey treatment offers no hope and you would simply be wasting your money." K. L. Milstead to RS [De Queen, Arkansas], I August 1956, Accession 63A292. Box 526, Folder I4, FDA archives. See also K. L. Milstead to AIB [Broadwater, Nebraska], is February I957, Accession 63A292, Box 529, Folder 47, FDA archives; K. L. Milstead to LBM [East Flat Rock, North Carolina], 24 July I956, Accession 63A292, Box 526, Folder I I, FDA archives; K. L. Milstead to PJ 
the wrong sort of hope-the "false hope" of a cure for incurable cancers, as one FDA official called it. ${ }^{24}$ His clinic, another official warned, was "a place where a great many people have been going under the false hope that Mr. Hoxsey has a treatment for cancer only later to be forced to recognize the truth; namely, that his treatment is worthless." ${ }^{25}$ To such officials, the particular danger that Hoxsey posed was that he encouraged patients to delay in seeking help from a recognized physician until after the best opportunities for effective intervention were gone. As John Heller, Director of the National Cancer Institute (NCI), noted in I953, congratulating the FDA for one of its many attacks on Hoxsey:

Our efforts in cancer control are directed toward reduction of the intervals between onset and diagnosis of cancer, and between diagnosis and the application of effective treatment. People who fall victims to quacks are diverted from this narrow course for the best clinical management of cancer. ${ }^{26}$

Officials also worried that Hoxsey's ability to target real limitations in the effectiveness of orthodox approaches to cancer undermined any faith in their ability to treat the disease. It was difficult to disagree with Hoxsey that orthodox approaches to cancer were often of little help to patients, but cancer agencies argued that they still offered the best chance of a cure. "[E]ven though medical science has not advanced to the point where a cure can be promised," an FDA official pleaded with one patient tempted by Hoxsey, ". . . the only hope for those afflicted with cancer is to have faith in experts in the field of cancer." 27

But it was often an uphill task persuading people to maintain such faith and to agree with them on who was an expert, and Hoxsey complicated the matter with vigorous attacks on his medical critics.

[Nolanville, Texas], I 3 August 1956, Accession 63A292, Box 526, Folder I7, FDA archives; K. L. Milstead to CAG [Wheeler, Texas], 9 August 1956, Accession 63A292, Box 526, Folder I6, FDA archives; and K. L. Milstead to CH [Conway, South Carolina], 9 August I956, Accession 63A292, Box 526, Folder I6, FDA archives.

24. W. R. Moses (Chief of the FDA's New Orleans's Station), "Injunction Recommendation," I4 August 1947, 25, Accession 63A292, Box 526, Folder AF27-026, FDA archives.

25. K. L. Milstead to CHJ [Los Angeles, California], I August 1956, Accession 63A292, Box 526, Folder I4, FDA archives.

26. J. R. Heller to Mr. C. W. Crawford, Commissioner of Food and Drugs, 5 November I953, Accession 63A292, Box 525, Folder AF27-026 (W-C) 5, FDA archives.

27. K. L. Milstead to LM [Leigh, Nebraska], 5 July I956, Accession 63A292, Box 525 , Folder AF27-026 (W-C) 4, FDA archives. See also K. L. Milstead to LH [Colorado Springs, Colorado], 29 March I957, Accession 63A292, Box 529, Folder 53, FDA archives. 
In his view, such critics misled the public with exaggerated claims about their ability to treat cancer, only to abandon their patients as "hopeless" once the limits of their therapeutic methods became apparent. Other physician critics, he argued, erroneously regarded all cancers as hopeless. The result was the same: physicians betrayed their patients by regarding them as hopeless when they were not; by denying them the benefits of the Hoxsey treatment; and by spreading the "contagion" of hopelessness. ${ }^{28}$ For such reasons Hoxsey urged his readers to pay attention to the "faint spark of hope"29"fanned into bright flame" ${ }^{30}$ — that they might feel on reading about his treatment, and to ignore all attempts by orthodox physicians to douse such flames. A widely printed advertisement (see Figure 2) claimed that the Hoxsey clinic offered "more than hope," though (as the text suggests) not the certainty of a cure. ${ }^{31}$

It was in this context that in April 1956 the FDA took the unprecedented step of issuing a public warning to people not to seek treatment from Hoxsey and inviting them to write for more information. As previously mentioned, the response was overwhelming. Of the 9, I 80 responses that survive, the vast majority were straightforward requests for more information, but around I,5 I6 wrote more, from a few extra lines to many pages. Most attacked the FDA for its campaign, a few wrote in support, and others provided information on their ills and their experience with physicians and with Hoxsey (whom they also spelled Hoxey, Hoxy, and Hoxie). They told of their understandings of cancer, their concerns for family and friends, their attitudes toward the FDA's action, and their thoughts on surgery, radiotherapy, cancer research, quackery, and many other issues. Most important for my purpose, some also wrote about "hope": why they had hope of Hoxsey or orthodox medicine; how they sought to deal with "hopelessness"; and how they decided on what was hopeful and what was not. They also wrote about the value of hope as a comfort for the hopeless and the ways in which

28. Hoxsey, You Don't Have to Die, 7. Harry M. Hoxsey, "You Don't Have to Die," Life Today and Your Mind Power, Jan.-Feb. I957, 10(1), 73-90, 77.

29. Hoxsey, You Don't Have to Die, 2; Hoxsey, "You Don't Have to Die," 73.

30. Hoxsey, You Don't Have to Die, 2; Hoxsey, "You Don't Have to Die," 74.

3I. "Proof Positive! Cancer Cures after Usual Methods Failed. Hoxsey Cancer Clinic. Offers You More than Hope!” New Phys. Cult., March I948, 92(2), 47. 


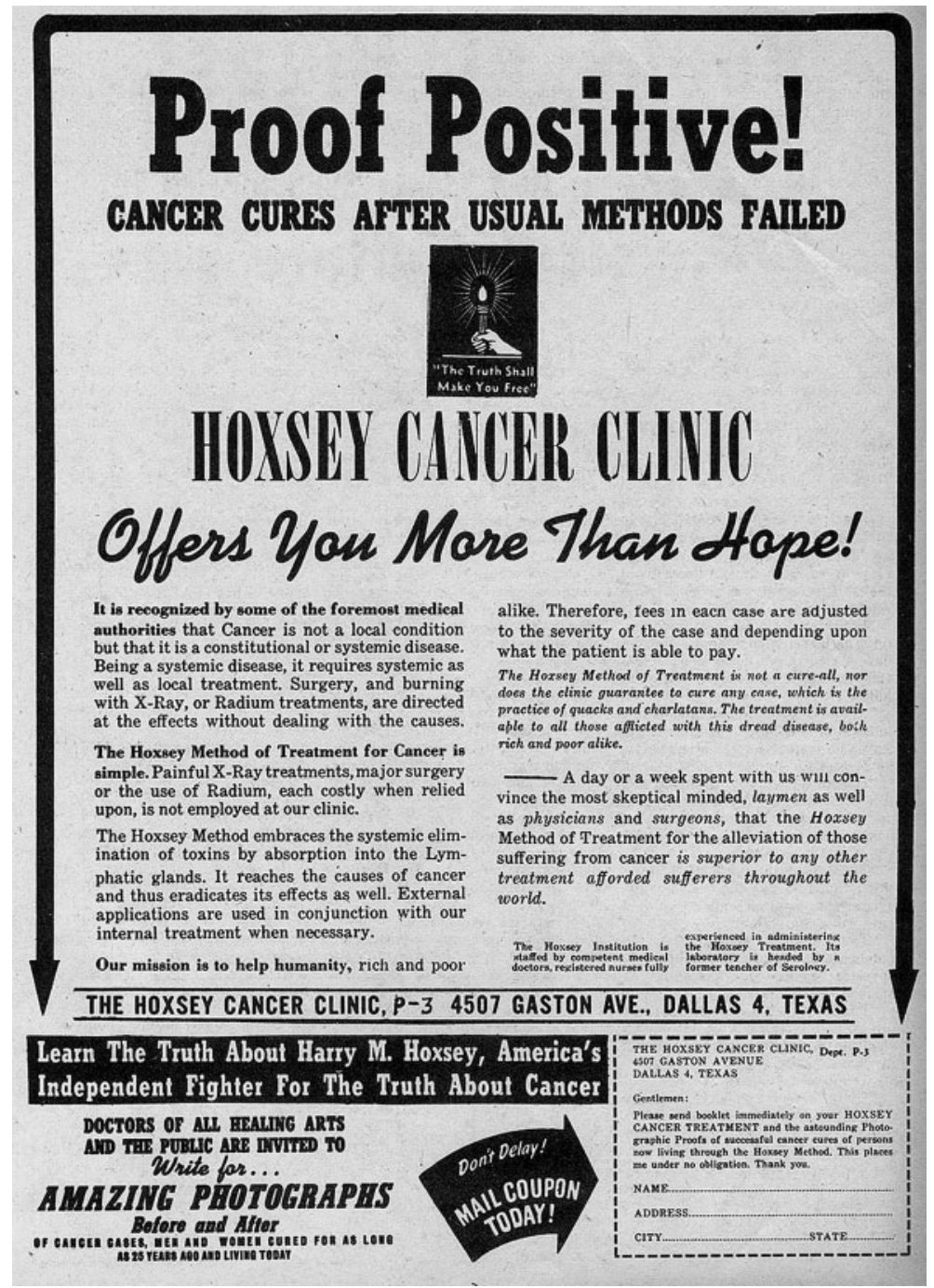

Fig. 2. New Physical Culture, March 1948, 92(2), 47. Courtesy of the American Medical Association Archives, Historical Health Fraud and Alternative Medicine Collection.

hope might be exploited by commercial, political, or supernatural interests and agencies. The analysis that follows is based on a sample of 23 I letters that employ the term "hope." 
For many reasons, this collection is a problematic source. The files seem to have been weeded at some point in the past. ${ }^{32}$ The sample that survives is biased toward critics of orthodox medicine; there are hints of organized letter-writing campaigns against the FDA; and the information on those who wrote is often limited. It can be difficult to infer occupation, class, marital status, ethnicity, religious affiliation, and even gender from these letters; sometimes all we have is an initial, a surname, and a return address, and ethical and practical considerations have restricted follow-up. Some letters are anonymous. Nevertheless, these letters offer a valuable window onto how supporters and opponents of Hoxsey engaged with the competing messages of hope put out by Hoxsey and the cancer agencies and what this tells us about vernacular meanings, epistemologies, and imaginative uses of hope.

The letters can be divided into two groups: those who supported Hoxsey, and a smaller number of doubters. Many of the former appear to have come from evangelical Protestant backgrounds. ${ }^{33}$ They affirmed the authority of the Bible, the necessity of conversion, and the duty of holy living. They used their letters as an opportunity to evangelize, to seek converts among government officials, and to warn of the dangers of abandoning Jesus. They tended to see America, their homeland, as abandoning the faith of their parents and grandparents. Their responses to the FDA can, therefore, be seen as part of a broader story of the separation and marginalization since the I920s of evangelical Protestantism from mainstream Protestantism and from broader American society. ${ }^{34}$ In the I950s, anxieties about such marginalization were given added impetus by the Cold War crusades against godless communism and anxieties about the impact of big business on the small man and woman. Letter

32. Some of the boxes in the FDA's collection appear to be missing. Also, within the surviving five boxes there are a number of folders (approximately twelve of the total of fifty-three folders) that are empty, perhaps the result of earlier weeding, or of the consolidation of letters into other folders.

33. On Hoxsey's patients, see Juhnke, Quacks and Crusaders, especially ch. 4. For a more general discussion of why people turned to alternative healers, see Barbara Clow, Negotiating Disease. Power and Cancer Care, 1900-1950 (Montreal and Kingston: McGill-Queens University Press, 200I).

34. For a useful survey of the substantial literature on evangelical Protestantism in the twentieth century, see D. G. Hart, That Old-Time Religion in Modern America. Evangelical Protestantism in the Twentieth Century (Chicago: Ivan Dee, 2002). 


\section{Journal of the History of Medicine : Vol. 61, July 2006}

writers tended to see conspiracies of communists within government and to worry about the restrictions placed by business organizations - including organized medicine-on individual freedom and choice. Despite an evangelical emphasis on renunciation of the world, these individuals were willing to engage with the world when threatened by communists, corporations, and cancer.

The smaller group of doubters is more difficult to characterize. Many expressed no religious opinion or wrote in ways that suggest a liberal modernist church background. They were generally less willing than Hoxsey's supporters to see direct personal experience of a cure as a means of countering medical knowledge or authority. They were also generally less willing than Hoxsey's supporters to see conspiracies of communists and big business against them. They were less critical of government and organized medicine, nor were anti-Catholic or Jewish sentiments as evident as among Hoxsey's supporters. Some doubters identified themselves as Jewish or Catholic. Many letters suggest a higher level of formal education than among Hoxsey's supporters. ${ }^{35}$

I write of tendencies within these letters. Hoxsey's supporters tended toward evangelical, and sometimes fundamentalist, Christianity; Hoxsey's doubters tended toward mainstream Protestantism and other denominations and religious traditions. Each side tended toward different attitudes on medicine, government, big business, and communism. Yet individuals were not consistent in their letters, and groups were often divided in their response to Hoxsey. Thus, individual supporters might criticize government agencies at the same time as they appealed for help from the same agencies; evangelical Christians were divided over Hoxsey's association with faithhealing, and over the value of personal experience or correct belief in assessing the hope he offered; and, despite the anti-Catholic and anti-Semitic tendencies of his supporters, Hoxsey found support among Catholics and Jews. Supporters and doubters thus shaded into one another, degrees along a spectrum, distinct at the extremes, but blurring into each other.

35. Patterson notes that supporters of Hoxsey in the NCI collection he examined were "poor and ill-educated." Patterson, Dread Disease, I06, I63. For a critique of Patterson's assessment of the educational attainment of supporters of Hoxsey and other "quacks," see Barbara Clow, Negotiating Disease, I04-7. 


\section{Out of Hopelessness}

Many of those who corresponded with the FDA regarding its campaign against Hoxsey echoed his comments. The hope that Hoxsey offered was-as cancer experts feared, and Hoxsey acknowledged (see Figure 3) - a product of the fact that many doctors regarded cancer as a "hopeless" condition.

Many complained that their physicians did little more than diagnose them or their family and friends as hopeless and then leave them to die, and it was for this reason that they turned to Hoxsey. ${ }^{36}$ In numerous letters, supporters and opponents alike acknowledged that all too often he was their "only hope," 37 someone to turn to "when all hopes were gone." ${ }^{38}$ He cured some of cancer when they
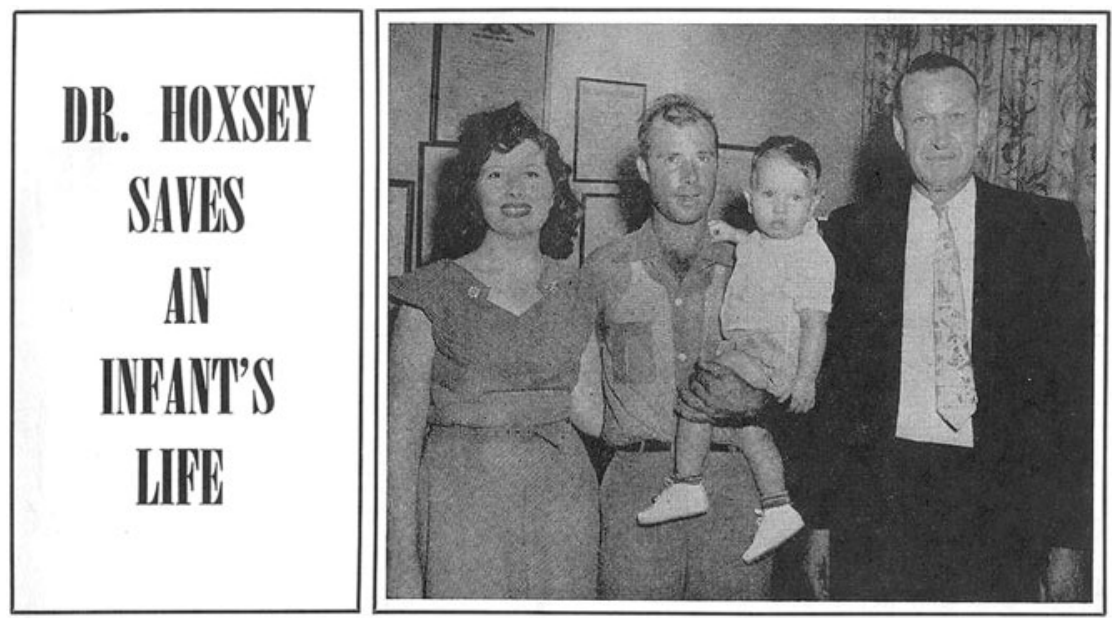

Mr. and Mrs. Leon Seago of Rockdale, Texas and their baby boy are shown with Dr. Harry M. Hoxsey in the above picture. In April 1953 the infant was found to have cancer and pronounced hopeless. Today he is a fine, healthy bouncing boy .... thanks to the Hoxsey cancer treatment.

Fig. 3. The Defender Magazine, January I955, 29(9), 9. Courtesy of the American Medical Association Archives, Historical Health Fraud and Alternative Medicine Collection.

36. EA [Regent, North Dakota] to FDA, is July I956, Accession 63A292, Box 526, Folder I2, FDA archives.

37. WAB [Black Rock, Arkansas] to G. P. Larrick, I February I957, Accession 63A292, Box 529, Folder 47, FDA archives.

38. AC [Roseburg, Oregon] to K. L. Milstead, I2 February I957, Accession 63A292, Box 528, Folder 30, FDA archives. 


\section{Journal of the History of Medicine : Vol. 61, July 2006}

were "in despair and hopeless about it," 39 and gave hope to family relatives, such as the son whose father was cured by Hoxsey so that "we all had hope for him." "Critics argued that Hoxsey exploited such hopes for financial gain, and that his cures did little good and much harm. But what was someone abandoned by regular medicine to do? "What are you going to do if they, (the Dr's) of Omaha send you home and say there is no hope, you have cancer and we can't help you," asked one woman from Nebraska, requesting help from the FDA for her brother. "All they do around here is say its to [sic] late can't help you no more just give them so many months to live [.] I sure can't see it that way if there still is a place that there is [a] little hope like we found [in Hoxsey.]"

The FDA responded to another correspondent that it was very rare for a reputable doctor to "advise a patient that his case is hopeless. Usually this is the conclusion of the patient and not of the doctors." ${ }^{2}$ But whether or not the FDA was right about the doctor's advice, patients often did conclude that they were regarded as hopeless, and they turned to Hoxsey as a consequence. Thus one son saw Hoxsey as "a possible hope" for the cure of his mother, "given up to die by our medical doctor." 43 A woman from San Diego, California, noted that a young man in her church turned to Hoxsey because "the doctors do not give much hope for his recovery." ${ }_{44}$ Another woman from Carson City, Nevada, whose brother-in-law had had surgery and radium, reported that "the Drs. say there is still no hope for him." 45 Many noted that they knew of so-called hopeless cases cured by Hoxsey. One stated that "our minister's father was cured over 9 yrs. ago at Hoxsey Clinic after being given no hope by

39. TRM [Crossville, Tennessee] to Mr. Larrick, I March I957, Accession 63A292, Box 529, Folder 49, FDA archives.

40. DLK [Sioux City, Iowa] to FDA, I3 February I957, Accession 63A292, Box 529, Folder 48, FDA archives.

4I. LM [Leigh, Nebraska] to "Dear Friends!" FDA, 30 June I956, Accession 63A292, Box 525, Folder AF27-026 (W-C) 4, FDA archives.

42. K. L. Milstead to RE [Waldron, Arkansas], 7 August I957, Accession 63A292, Box 526, Folder I 5 , FDA archives.

43. PK [Brookfield, Missouri] to FDA, 9 April I957, Accession 63A292, Box 529, Folder 54, FDA archives.

44. EMC [San Diego, California] to FDA, 4 February I957, Accession 63A292, Box 528, Folder 29, FDA archives.

45. LCH [Carson City, Nevada] to FDA, I6 February 1957, Accession 63A292, Box 529, Folder 48, FDA archives. 
Drs," ${ }^{46}$ while another wrote of a man cured by Hoxsey after being informed by the Mayo Clinic that "there was no hope for him." 47 The tragedy in the last example-reported in a letter written by a woman from Pipestem, West Virginia — was that this man had been cured of the same type of cancer that had killed her father. As one Texas woman whose mother had been cured by Hoxsey told President Eisenhower: "If you have ever seen someone you loved with the above mentioned diseases you can well imagine how I feel with Larrick of Food \& Drug trying to close Hoxseys." ${ }^{48}$ George P. Larrick was the FDA Commissioner.

As such remarks suggest, many commentators were aghast at what they saw as the temerity of the FDA in attacking Hoxsey, given the poor state of medical knowledge about cancer. Some were angered at taxpayers' money going to attacks on an institution that had brought "extended years of life and happiness to hundreds of patients, many of whom had been given up as hopeless by the medical profession." 49 It was a common story that the "cured" patient would later return to the doctor after treatment by Hoxsey. As one put it, "he [the doctor] certainly was surprised to see me. He didn't expect to see me alive any more." 50

Not everyone was persuaded that Hoxsey did provide a cure. But even doubters could be persuaded that the hope he offered was psychologically beneficial. For example, one noted that after attending Hoxsey's clinic, her brother-in-law (given up for dead by orthodox

46. JFC [Mutual, Oklahoma] to K. L. Milstead, 28 February I957, Accession 63A292, Box 529, Folder 49, FDA archives. See also JFC [Mutual, Oklahoma] to FDA, I 4 February I957, Accession 63A292, Box 529, Folder 48, FDA archives. JFC [Mutual, Oklahoma] to G. P. Larrick, 3 July 1956, Accession 63A292, Box 525, Folder AF27-026 WC (6), FDA archives.

47. GN [Pipestem, West Virginia] to Congresswoman Elizabeth Kee, 23 February I957, Accession 63A292, Box 529, Folder 5I, FDA archives. See also GN [Pipestem, West Virginia] to The Market Bulletin, State Department of Agriculture, 23 February I957, Accession 63A292, Box 529, Folder 49, FDA archives. GN [Pipestem, West Virginia] to G. P. Larrick, 26 July I956, Accession 63A292, Box 526, Folder I 8, FDA archives.

48. TJA [Brownwood, Texas] to President Eisenhower, I2 February 1957, Accession 63A292, Box 529, Folder 49, FDA archives.

49. EPJ [Los Angeles, California] to Marion B. Folsom (Secretary DHEW), 2 March 1957, Accession 63A292, Box 529, Folder 5I, FDA archives. Others concerned about the use of taxpayers' money include CB [Cadillac, Michigan] to K. L. Milstead, I8 February 1957, Accession 63A292, Box 529, Folder 47, FDA archives.

50. AK [La Feria, Texas] to U.S. Dept. of Health and Education, 25 March 1957, Accession 63A292, Box 529, Folder 53, FDA archives. See also FR (unsigned) [Los Altos, California] to Chairman and members of this Committee, 25 March 1957, Accession 63A292, Box 529, Folder 54, FDA archives. 
physicians) was once again interested in living: "We don't know if he will be cured, although he has shown improvement, but if nothing else it has given him hope and happiness." dent from Rockville Centre, New York, picked up on a medical justification for such hope, noting that while Hoxsey's treatment "may not be a cure all it does increase a patient's hopes which is in itself something that even the medical [profession] want [,] this increase of 'hope' [,] particularly as other means appear to have no real benefit." ${ }^{52}$ Another doubted that Hoxsey promised a cure but still saw benefit in his treatment. The world, he noted, was waiting to hear of a cure for cancer: "it brings hope to the hopeless," and he criticized what he called the Health department for dousing "any hopes the Cancer victim has of even becoming partially cured.",

So it was that many commentators mixed a medical or psychological justification of the "hope" offered by Hoxsey with commentaries on medicine's own ineffectiveness against the disease. Hoxsey, the argument went, offered psychological benefit, and it was not always clear to letter writers what the FDA's campaign against Hoxsey offered in its stead. Indeed, given the belief in medicine's ineffectiveness against cancer, the campaign seemed to destroy even the possibility of hope for those who had none. Some among those sympathetic to the FDA's campaign found that it raised some very difficult issues. What were they to tell friends or family who found hope in Hoxsey and little elsewhere? What would be left for them if their hopes were shattered? "Would it be wrong to destroy her hope?" one correspondent asked the FDA of a friend who had cancer and was attending the "Hoxie" clinic. ${ }^{54}$

Among critics of the FDA, the psychological benefits of hope were not, however, the main concern. For most such critics, Hoxsey

5I. EG [Hawley, Minnesota] to U.S. Dept. of Health, 8 February 1957, Accession 63A292, Box 529, Folder 47, FDA archives. The FDA did not have a specific response to the point about hope and happiness. Instead it commented that claims that Hoxsey's treatment was effective were not supported by the scientific evidence and that laymen were not qualified to assess whether they had been cured of cancer. K. L. Milstead to EG [Hawley, Minnesota], I6 February 1957, Accession 63A292, Box 529, Folder 47, FDA archives.

52. JTC [Rockville Centre, New York] to K. L. Milstead, 25 March I957, Accession 63A292, Box 529, Folder 53, FDA archives.

53. DOW [Fairfax, Virginia] to G. P. Larrick, I9 August I956, Accession 63A292, Box 526, Folder I8, FDA archives.

54. AIB [Broadwater, Nebraska] to FDA, 7 February 1957, Accession 63A292, Box 529, Folder 47, FDA archives. 
offered not merely a psychological benefit but a real cure. "I have had personal contact with patients [one noted] who are taking the Hoxey treatment-some of them were hopeless cases given up by the M.D.'s. They are now back on their feet, feeling good and working." 55 Another noted that she knew of "several that the M.D.s. gave no hopes of living that went there [to Dallas] \& were cured." ${ }^{56}$ Another wrote that the Hoxsey Clinic at Portage, Pennsylvania, gave cancer sufferers "new life, new hope, and placed them back into society, and sent them home to their loved ones after being told their cases were hopeless by medical doctors previously." ${ }^{57}$ With so much good news emanating from Dallas and Portage, many echoed Hoxsey's own claims that his clinics tended to attract patients that had been given up as hopeless by the medical profession ("They seldom gets a cancer patient that hasn't been given up as hopeless by the M.Ds, and they cure many of them"58; "The ones the Hoxsies are getting is the ones that un-Curable and beyond hope $\left.{ }^{, 59}\right)$. How unjust the FDA's action seemed in such light: "Of course I know and I know that you know," noted one critic of the FDA, "that the Hoxsey Clinic has cured hundreds of cases of both internal and external cancer after all other treatments had failed and their cases been pronounced hopeless." "[Y] ou [another told George Larrick] should stop to consider the people who have only the hope of Hoxsey Clinic because with cancer there is no other hope."

Part of the reason for such an emphasis on Hoxsey's ability to cure cancer was tied to criticisms of certain trends in modern medicine. The first was a critique of medical research, support for which was growing as never before in the I950s. ${ }^{62}$ At a time when Hoxsey

55. SP [Pontiac, Michigan] to Senator Charles E. Potter, n.d., possibly February I957, Accession 63A292, Box 529, Folder 47, FDA archives.

56. JFC [Mutual, Oklahoma] to G. P. Larrick, 3 July I956, Accession 63A292, Box 525 , Folder AF27-026 WC (6), FDA archives.

57. MDA [Kingston, Utah] to Senator Wallace F. Bennett, i6 April i956, Accession 63A292, Box 525, Folder AF27-026 (W-C) 7, FDA archives.

58. BVM [Jonesboro, Illinois] to G. P. Larrick, 30 January I957, Accession 63A292, Box 528, Folder 29, FDA archives.

59. RE [Waldron, Arkansas] to FDA, I4 January I957, Accession 63A292, Box 528, Folder 28, FDA archives.

60. HHH [Anthony, Texas] to George P. Larrick, 25 February I957, Accession 63A292, Box 529, Folder 49, FDA archives.

6I. Mrs. S [Ontario, California] to G. P. Larrick, 6 August I956, Accession 63A292, Box 526, Folder I8, FDA archives.

62. Patterson, Dread Disease, ch. 7. 
argued that orthodox medicine refused to investigate his cures, some correspondents demanded that the examination of Hoxsey's claims should be given priority over other areas of research. ${ }^{63}$ Others questioned the need for research at all. In their view, research might promise the hope of a cure, but it did so only in the future. Hoxsey, by contrast, offered it now. It was an oft-stated comment that cancer researchers claimed that Hoxsey offered little or no hope and yet had nothing to offer in its place. As one commentator put it: "If the Hoxsey treatment is worthless then have the Cancer research foundations anything with more hope in to offer?" ${ }^{64}$ None of this is to say that critics of the FDA gave up all hope in research. If people turned in desperation to those whom orthodox medicine regarded as quacks, they also turned in desperation to the very researchers they had doubts about. A critic of cancer research foundations makes the point. His wife had breast cancer, and for all his doubts about the hope offered by such foundations, he was unwilling to abandon them entirely. If, he asked, the FDA did think that the cancer research foundations offered more hope than Hoxsey, then "If so could my wife get admitted to such a reputable foundation, Bethesda being one?" ${ }^{65}$ As the daughter of a father who had recently died of cancer noted, "We would gladly have tried any research drug, [if] even a slight hope was given." 66

If hopes in Hoxsey involved a critique of research, they also involved a critique of surgery and radiotherapy, the mainstays of orthodox treatments. All too often, critics claimed, these "cures" offered no hope at all, despite the faith vested in them by orthodox medicine. Time after time people had to watch loved ones die after undergoing dreadful torture, such as the woman whose daughter "was one year sick the Dr Cutting and Burning her up she was Baked Brown frying and such a death." ${ }^{67}$ Repeatedly the medical profession was criticized for announcing cures by surgery, $\mathrm{X}$ rays,

63. See also Fred Gaodenhine (sp.?) to Herb Graffis, 24 December 1954, Box 0367, File 08, Health Fraud Collection, AMA archives.

64. WRP ["St John, Virgin Islands, U.S.A."] to FDA, I4 January I957, Accession 63A292, Box 528, Folder 28, FDA archives.

65. Ibid.

66. GN [Pipestem, West Virginia] to G. P. Larrick, 26 July I956, Accession 63A292, Box 526, Folder I 8, FDA archives.

67. PH [North Sacramento, California] to FDA, I4 February I957, Accession 63A292, Box 529, Folder 48, FDA archives. 
and radium, only to find that those allegedly "cured" by such methods subsequently died, often after considerable expense. ${ }^{68}$ As with research, many people turned to the very therapies they had doubts about; the disease was too serious to give up hope, even in such "hopeless" treatments. Yet they continually worried about such reliance. Perhaps with such concerns in mind, a Kansas couple blamed the FDA's poster campaign for forcing individuals to rely on such hopeless treatments: "it's a shame that so many more victims of cancer will be doomed to expensive radium treatments and surgery with no hope either." ${ }^{69}$

As these comments suggest, many were concerned not only about the alleged ineffectiveness of orthodox treatments, but also about their cost. As one Hoxsey supporter put it:

Have you ever paid hundreds of dollars to Medical doctors and the same to surgeons in the hopes of being cured or even improved in health as a victim of cancer only to grow worse continually, and after you had spent precious time and money to have Specialists tell you they could do nothing more for you and send you home to die? ${ }^{70}$

Estimates of Hoxsey's fees vary-the FDA suggested that he charged around $\$ 460$ for a treatment (see Figure I) - but, whatever the charge, it was often regarded as cheaper than orthodox treatments. One wrote that if a man in her neighborhood-now in the gravehad gone to Hoxsey, "he would have had the hope of living and not near the cost as Rochester [the Mayo Clinic, the butt of much criticism]". ${ }^{71}$ Another noted that the Mayo Clinic had charged \$I 200 only to send her husband home to die, while Hoxsey had cured him for \$400: "you dont [sic] know \& I hope you never do, [she told George Larrick] what an ofel [sic] thing a cancer is[.]"72

68. HC [Mesa, Arizona] to U.S. Department of Health, 24 February 1957; TH [Cedar Rapids, Iowa] to John L. Harvey [Deputy Commissioner FDA], February I957, Accession 63A292, Box 529, Folder 48, FDA archives.

69. Mr. \& Mrs. LES [Wichita, Kansas] to FDA, 26 February I957, Accession 63A292, Box 529, Folder 50, FDA archives.

70. AC [Roseburg, Oregon] to K. L. Milstead, I2 February 1957, Accession 63A292, Box 528, Folder 30, FDA archives.

7I. CJ [Frost, Minnesota] to Health, Education and Welfare, 30 July 1956, Accession 63A292, Box 526, Folder I7, FDA archives.

72. Anonymous [Independence, Missouri] to G. P. Larrick, I 8 July I956, Accession ${ }_{63} \mathrm{~A} 292$, Box 526, Folder I0, FDA archives. For comments on how a combination of the expense and pain of radiation and surgery dissuaded an individual from seeking orthodox treatment, see RWM [Falmouth, Massachusetts] to FDA, 8 March 1957, Accession 63A292, Box 529, Folder 51, FDA archives. RWM concluded: "we have been hoping and praying that the Hoxsey treatment might be the answer to her desperate need." 


\section{Journal of the History of Medicine : Vol. 61, July 2006}

If orthodox medicine offered little or no hope, then many commentators wondered why it continued to promote its treatments. "Why do doctors operate when they know the case is hopeless?", asked one Arkansas correspondent after noting that medical science could not cure cancer, the proof of which was a neighbor operated on and sent home to die. ${ }^{74}$ The answer for some was money. Physicians were always after their fee. "I have known of many "exploratory operations' on hopeless cases; and why?" asked one, "because of the fee involved."75 Many pointed out that the AMA was concerned about Hoxsey only because they had no financial control over him. ${ }^{76}$ They had nothing to offer: they didn't have a cure and didn't want Hoxsey to have it. Professional jealousy and greed were involved: "Please, Man you know they are doing good. get rid of that jealous, hatred spirit and let the Hoxsey alone." 77 For such reasons, they often argued that the FDA was only doing the AMA's work for them; a "friend" noted one who would destroy "Hoxie" for a "consideration". "78 "I hope you want [sic] overlook the fact [one critic wrote his congressional representative]: The battle is between the American Medical Association (directly or indirectly) and Dr. Harry Hoxsey." 79 Repeatedly, commentators criticized the AMA as a monopoly previously attacked by New Dealers. ${ }^{80}$ It sought not only to restrict competition, but also to undermine consumer

73. WFL [Low Gap, Arkansas] to FDA, 4 March I957, Accession 63A292, Box 529, Folder 50, FDA archives.

74. Paradoxically, having noted that it was known that medical science could not cure cancer, this writer then asked, "Can sience [sic] cure canser [sic]? I desire all the fact [sic] in the issue." WFL [Low Gap, Arkansas] to FDA, 4 March 1957, Accession 63A292, Box 529, Folder 50, FDA archives.

75. Dr. JDM D.O. [Jasper, Missouri] to K. L. Milstead, I6 March I957, Accession 63A292, Box 529, Folder 5I, FDA archives.

76. GN [Pipestem, West Virginia] to The Market Bulletin, State Department of Agriculture, 23 February I957, Accession 63A292, Box 529, Folder 49, FDA archives.

77. Quotation in RE [Waldron, Arkansas] to FDA, 30 March I957, Accession 63A292, Box 529, Folder 53, FDA archives. See also TRM [Crossville, Tennessee] to Mr. Larrick, I March 1957, Accession 63A292, Box 529, Folder 49, FDA archives; DM [Texarkana, Arkansas] to G. P. Larrick, 23 February I957, Accession 63A292, Box 529, Folder 49, FDA archives; MB [Smith, Nevada] to G. P. Larrick, I 8 February I957, Accession 63A292, Box 529, Folder 49, FDA archives; and JWP [College Point, Long Island, NY] to G. P. Larrick, 6 April 1957, Accession 63A292, Box 529, Folder 53, FDA archives.

78. WNP [Richmond, Virginia] to "His Excellency The President of the U.S.," Io July I956, Accession 63A292, Box 526, Folder I2, FDA archives.

79. WEM [Orange, Texas] to Representative Jack Brooks, Io March I957, Accession 63A292, Box 529, Folder 53, FDA archives.

80. HHH [Anthony, Texas] to George P. Larrick, 25 February I957, Accession 63A292, Box 529, Folder 49, FDA archives. 
choice: "If the public are satisfied with them [Hoxsey] and they offer a source by which they can hold out a hope of cure then why should they be deliberately ridden out of business by their competitors?" 81

Related to these concerns about financial and competitive pressure was a critique of quackery within medicine. ${ }^{82}$ For some, orthodox treatments were "the most damnable quackery ever invented by the devil." "83 Many also associated quackery with financial corruption and deceit. "Only 'quacks' administer surgery, X-ray and radium," mented one writer, concluding: "A quack is one who cuts and bleeds and burns and collects, while knowing and admitting that the method of treatment being used offers no hope for the patient." "Figure it up. Mr.," wrote another, "so who's the Money Grabbers \& who are the Quacks on Cancers, Yes the Poorly Educated MD's by the A.M.A.",85 Another noted that Hoxsey "has been called a quack. I wonder who is the worst quack, the M.D. who takes your money and gives those horrible treatments ... when they honestly know it is no help, or the so called painless cure of the Hoxsey Clinic." 86

8I. HWH [El Paso, Texas] to Lyndon B. Johnson, i I February I957, Accession 63A292, Box 529, Folder 47, FDA archives.

82. Occasionally FDA officials were also labeled quacks, as one critic asked George Larrick, "did you ever stop to think you might not be the man for your job, you might be a quack in your field." Anonymous [Independence, Missouri] to G. P. Larrick, I 8 July I956, Accession 63A292, Box 526, Folder IO, FDA archives. Many of the criticisms that follow in the next few paragraphs echo those that Hoxsey himself made. See for example Young, Medical Messiahs, 382. Hoxsey himself often called orthodox physicians "quacks"; see for example his talk "Who Are the Real Quacks" in RMS's report on the Joint Convention of the American Naturopathic Association in I955, dated I2 September I955, Box 0365, File 02, Health Fraud Collection, AMA archives.

83. E. B. Hartman to John L. Harvey [Deputy Commissioner, DHEW], 4 March I957, Accession 63A292, Box 529, Folder 49, FDA archives. Hartman worked at the De Sienna Treatment Rooms of San Bernardino, California, which offered "Battle Creek Treatments" and Hot Mineral Baths, sound treatment, spinal adjustments, colon therapy, and sacroiliac correction. See also E. B. Hartman to The President of the United States, the Attorney General of the U.S. and the Postmaster General of the U.S., I2 February 1957, Accession 63A292, Box 529, Folder 49, FDA archives. Emerson B. Hartman, Professional Secrets for Doctors and Laymen (San Bernardino, Calif.: No Publisher, ca. I955), copy in NLM, call number WB $905 \mathrm{H}_{333 p}$ I955 [2nd rev. and enl. ed., I957], call number WB $905 \mathrm{H}_{333 p}$ I957.

84. DM [Texarkana, Arkansas] to G. P. Larrick, 23 February I957, Accession 63A292, Box 529, Folder 49, FDA archives. This use of "quack" echoes a report in the Defender magazine "Letters to Larrick" [n.d., probably I956], 3, Accession 63A292, Box 526, Folder I2, FDA archives.

85. RLK [Covina, California] to FDA, I 8 February I957, Accession 63A292, Box 529, Folder 47, FDA archives.

86. HW [Toledo, Ohio] to G. P. Larrick, 30 June I956, Accession 63A292, Box 526, Folder I5, FDA archives. 


\section{Journal of the History of Medicine : Vol. 61, July 2006}

It was such concerns about financial corruption in medicine that prompted many critics of the FDA to suggest that the label quack was quite inappropriate to Hoxsey. As one put it, the trouble was that " "quacks' has come to mean anyone who does not take orders from the A.M.A." ${ }^{\prime 87}$ Others saw a contradiction between the label "quack" and what they saw as the generosity, honesty, and openness of Hoxsey. "If Mr. Hoxsey is a quack why does he do so much for charity [?]" asked a woman from Leadwood, Missouri, with reference to the claim that Hoxsey treated $25 \%$ of his patients free of charge. "Wouldn't you say a quack would be defined, as a money grabber?" she noted, with reference to orthodox physicians. "He [Hoxsey] is not a quack [noted another]. He is honest, His clinics are true and honest; and help all they can." 90 Others picked up on Hoxsey's claim that the medical profession refused to test his treatments. "Quack doctors cover up their procedures and elude investigation," noted a retired minister, turning medical arguments about Hoxsey's secrecy on their head-for, in his view, Hoxsey invited investigation, while orthodox physicians did not. ${ }^{91}$ Others were less concerned with the label itself, as one asked, "who cares if he is called a 'quack' or not as long as he saves life." 92

If critics attacked the FDA for promoting quackery and commercialism within medicine, they also worried about its neglect of other issues. Many asked why the FDA was attacking someone like Hoxsey who did good, while ignoring issues such as fluoridation, tobacco, liquor, dope, and food adulteration, which, in the view of some, also caused cancer. ${ }^{93}$

87. LL [Long Beach, California] to President Eisenhower [n.d., probably December 1956 or January 1957], Accession 63A292, Box 528, Folder 27, FDA archives.

88. MFE [Leadwood, Missouri] to J. L. Harvey, 9 April I957, Accession 63A292, Box 529, Folder 54, FDA archives.

89. Ibid.

90. BA [Bakers Mills, New York] to The President and U.S. Government, I 8 January I957, Accession 63A292, Box 528, Folder 29, FDA archives.

9I. EWC [Toms Brook, Virginia] to Marion B. Folsom, I8 February I957, Accession 63A292, Box 529, Folder 49, FDA archives.

92. JWP [College Point, Long Island, NY] to G. P. Larrick, 6 April I957, Accession 63A292, Box 529, Folder 53, FDA archives.

93. Commentators who raised these themes include $\mathrm{HHH}$ [Anthony, Texas] to George P. Larrick, 25 February I957; LL [Long Beach, California] to Mr. Larrick, 28 February I957, Accession 63A292, Box 529, Folder 49, FDA archives; CT [McBride, Missouri] to G. P. Larrick, 23 February 1957, Accession 63A292, Box 529, Folder 48, FDA archives; JFC [Mutual, Oklahoma] to FDA, I4 February 1957, Accession 63A292, Box 529, Folder 48, FDA archives; JFC [Mutual, Oklahoma] to A. S. Goldhammer, 2 August 1956, Accession 63A292, Box 526, Folder I4, FDA archives; CCW [Battle Creek Michigan] to G. P. Larrick, 7 August I956, Accession 63A292, Box 526, Folder I5, FDA archives; LWS [West Concord, Minnesota] to FDA, [n.d., probably March/April I957], Accession 63A292, Box 529, Folder 53, FDA archives; EB 
For some, the explanation was obvious: the FDA was in the pay of industrial interests: "It seems there are so many government employees down there at Wash. getting a big fat salary, that should protect our citizens, instead of getting a bribe from the big drug, liquor, and refreshment interests. " ${ }^{, 44}$ Such comments also highlight how individuals challenged medically sanctioned notions of citizenship. In a I947 leaflet, the American Cancer Society (ACS) associated citizenship with people's willingness to support campaigns such as that of the ACS. ${ }^{95}$ But, the writer above hinted, the cancer agencies did not reciprocate by protecting those who supported it. She also highlighted the suspicion of government-and allegedly overpaid government employees - that pervades criticism of the FDA's action. In her view, such employees were somehow breaking contract with citizen-taxpayers who paid them for protection. The government worked for big business and not for the public, afraid, as another critic put it, to hurt "our tobacco growers and the feelings of chain smoking physicians and T.V. commercial payers." 96

Thus, the critique of the FDA brought together a broad range of popular concerns about corruption within government, medicine, and science, and of the role of vested interests in shaping government policy, all working against the small man or woman. ${ }^{97}$ To their

[Palmer, Nebraska] to FDA, 24 March I957, Accession 63A292, Box 529, Folder 54, FDA archives; RLK [Covina, California] to FDA, I 8 February I957, Accession 63A292, Box 529, Folder 47, FDA archives; EP [Los Angeles, California] to FDA, 7 July I956 [in an accompanying leaflet, EB gave an address at "No. Hope St."!], Accession 63A292, Box 525, Folder AF 27-026 (WC) 8, FDA archives; Anonymous to FDA, 20 December I956, Accession 63A292, Box 528, Folder 43, FDA archives. See also Chloe Hardy (Coutts, Alberta) to AMA, is January 1958, Box 0369, File 08, Health Fraud Collection, AMA archives. For an account of popular debates about fluoridation in the I950s, see Gretchen Ann Reilly, "This Poisoning of Our Drinking Water': The American Fluoridation Controversy in Historical Context, I950-I990" (Ph.D. diss., George Washington University, 200I). For contemporary medical and scientific attitudes toward environmental explanations of cancer causation, see Patterson, Dread Disease, i 87-90; Robert N. Proctor, Cancer Wars. How Politics Shapes What We Know and Don't Know About Cancer (New York: Basic Books, I995), especially ch. 2.

94. GF (Amston, Connecticut) to FDA, 30 June I956, Accession 63A292, Box 525, Folder AF27-026 (W-C) 3, FDA archives.

95. "Unless we Act I in 8 will die of Cancer," ca. I947, pamphlet, Health Fraud Collection, AMA archives.

96. ND [Newton Junction, New Hampshire] to FDA, I3 February I957, Accession ${ }_{63} \mathrm{~A} 292$, Box 529, Folder 48, FDA archives. For accounts of government attitudes toward smoking in the I950s, see Patterson, Dread Disease, 20 I-I6. Proctor, Cancer Wars, I05-Io. See also Allan M. Brandt, "Cigarette Risk and American Culture," Daedalus, I990, 119, I $55-76$.

97. For more recent criticism of vested interests shaping government policy, see Proctor, Cancer Wars. 


\section{Journal of the History of Medicine : Vol. 61, July 2006}

critics, government (and medicine and science) seemed remarkably unresponsive to popular opinion. Many writers argued that government worked hand in hand with organized medicine not only to undermine competition, but also to restrict consumers' ability to choose. In an age when mass consumption was supposed to deliver a more equal, free, and democratic nation, individuals worried about the impact of the restrictions imposed by big organizations on such ideals. ${ }^{98}$ Big government and big business were not only anticompetitive and anti-consumerist, they were also anti-democratic: "Couldn't thousands of these testimonials [noted one writer concerned about the Pittsburgh trial of the Portage Clinic] mean anything to these big organizations or are they heartless where individual lives are concerned? This country is still supposed to be a democracy." 99

Hoxsey's supporters also identified two other worrying tendencies within government. For some, government was a haven for communists intent on restricting freedom and fomenting trouble. Thus, one self-styled "red blooded American" noted that the FDA's action made it "possible for the communist to take over here without firing a shot. God forbid." 100 And others echoed the point. "Kill Kill, Kill, is all you Got in your Hearts so you communists can take over," commented one Hoxsey supporter to George Larrick, blurring the alleged murderous effects of surgical operations with the alleged murderous intent of communists. "Everyone of you ought to be shot," he wrote, "so that we can have a peacefull [sic] U.S. the way it should be." 102

Others were concerned not only with communism, but also with anti-Christian tendencies within government. Many saw the FDA as subverting what they saw as the Christian foundations of the nation:

98. Lizabeth Cohen, A Consumers' Republic. The Politics of Mass Consumption in Postwar America (New York: Alfred A. Knopf, 2003).

99. DZ [Comstock, Minnesota] to George Larrick, 23 January I957, Accession 63A292, Box 528, Folder 43, FDA archives.

I00. JLR [Independence, Missouri] to President Eisenhower, 27 January I957, Accession 63A292, Box 528, Folder 3 I, FDA archives.

Ior. RWV [Portage, Wisconsin] to G. P. Larrick, I 5 July I956, Accession 63A292, Box 526, Folder I2, FDA archives. The FDA responded, "While we respect your views you must realize that we disagree with them completely." K. L. Milstead to RWV [Portage, Wisconsin], 26 July 1956, Accession 63A292, Box 526, Folder I2, FDA archives.

I02. RWV [Portage, Wisconsin] to G. P. Larrick, I5 July i956, Accession 63A292, Box 526, Folder I2, FDA archives. For other attacks on communistic influences, see EP [Los Angeles, California] to FDA, 7 July I956, Accession 63A292, Box 525, Folder AF 27-026 (WC) 8, FDA archives. 
it was "condemning a Christian American ... [it was one of the] the destroyers of a Christian America." 103 Some saw satanic influences at work behind such efforts, others the workings of godless communism, and others the spiritual corruption of mammon. Even the claim that doctors refused to visit Hoxsey's clinic to evaluate his treatments could be construed as unchristian, as one commentator put it: "It is not American, Christian, or even fair, to judge a man without hearing his side of the story." ${ }^{104}$ Many took up such notions linking national identity with Christian salvation, fairness, and freedom. "I hope and pray for Dr. Hoxy that his wicked fighters [i.e., those opposed to him] come to naught and hope the Lord will save America from its wicked sins."105 "I am a Christian," the writer noted in an earlier letter, echoing the sentiments of other correspondents, "a law abiding citizen and I hope and pray our land may stay free." 106 Yet for all their claims that America was a Christian nation, letter writers often betrayed a concern that in fact the country was no longer Christian. American society had turned its back on the faith that had helped form the nation. Christians now felt like strangers in their own homeland, and the FDA and orthodox medicine were among the many agencies to blame for this state of affairs.

\section{Lies and Deceit}

It should be clear by now that, in their discussions of hope, Hoxsey's supporters also began to construct an image of the social world of cancer. This was a world in which medicine, government, and corporate interests worked (even conspired) against the small man or woman, inspired by commercial, communistic, and, sometimes,

I03. IS [El Monte, California] to Representative Patrick J. Hillings, I4 February I957, Accession 63A292, Box 529, Folder 48, FDA archives.

I04. ANT [Salina, Kansas] to Representative Myron V. George, I2 February I957, Accession 63A292, Box 529, Folder 48, FDA archives. And note the association of Christianity not only with Americanism and patriotism, but also with a fairness, apparently so lacking in government and among cancer experts - a point taken up by others. Thus, one Hoxsey supporter appealed to President Eisenhower to investigate the FDA because "I believe you to be a Christian and that you will be fair." JM [Ellsinore, Missouri] to President Eisenhower, I3 February I957, Accession 63A292, Box 529, Folder 48, FDA archives. I05. CWB [Peck, Michigan] to John L. Harvey, 22 March 1957, Accession 63A292, Box 529, Folder 53, FDA archives.

I06. CWB [Peck, Michigan] to President Eisenhower, 25 February 1957, Accession 63A292, Box 529, Folder 5I, FDA archives. 
satanic interests and agencies. ${ }^{107}$ It was also a world in which a few individuals stood up for the small man or woman against such vested interests, men like Hoxsey who worked selflessly for the greater good. Hope often provided an axis around which this world divided. If regular physicians exploited hope to promote their own interests, Hoxsey used it for healing. If regular physicians offered false hopes, Hoxsey offered the real hope of a cure. Regular physicians spread the "contagion" of hopelessness; Hoxsey inspired hope. Commercial, communistic, satanic, or other interests or agendas did not corrupt his motives. He supported Christian values against those of secularism and the devil. He was inspired by a desire to heal, charitable to the poor, and open to proof of the value or otherwise of his therapy.

Central to such a vision of the world was the commonsense belief that what people wrote or said about cancer should illuminate what was really known about the disease. Ideally, words should be a clear lens onto the disease and its treatment. The worry for many of Hoxsey's supporters was that the language of medicine and government seemed to fall far short of this ideal. Rather than provide a transparent window onto cancer and its treatment, it seemed to distort or to cloud the picture. The suspicion was that such distorted and cloudy images were deliberately produced. Hoxsey's supporters claimed that medicine and government knew that the Hoxsey cure worked, and they knew the limits of their own treatments; they simply chose to obscure this knowledge, mislabeling Hoxsey as a "quack," patients as "hopeless," and surgery and radiotherapy as the "only hope."

Against the backdrop of such mistrust, letters to the FDA often focused critically on medical language. Letter writers worried that physicians used esoteric terminology to mislead plain men and women not privy to its mysteries. They worried about the power of the label "hopeless" to persuade a patient to give up and die. And they worried about the power of the phrase "the only hope," applied to radiotherapy and surgery, to encourage "false hopes" in orthodox medicine. Suspicious of the motives behind such labels and phrases, they listened to medicine and government and heard lies and deceit. The point was made for one man from McBride,

107. For a history of conspiracy theories, see Daniel Pipes, Conspiracy: How the Paranoid Style Flourishes and Where It Comes From (New York: Free Press, 1997). 
Missouri, concerned about inconsistencies in the testimony of medical experts during the trial of the Portage Clinic:

I find that when a MD doctor says a person has cancer and he goes to Hoxsey and he is cured, then [according to the medical testimony] he didn't have cancer[,] but if he keeps going to the MD and he dies from x-ray and radium burns and cancer then [according to the medical testimony] he had cancer. ${ }^{108}$

Put another way, physicians tried to have it both ways. They denied Hoxsey's cures by the simple method of denying that his patients had the cancer in the first place. And, at the same time, they denied the deadly effects of their own treatments by suggesting that patients died of the cancer rather than the "cure." "The "The trial also proves," this correspondent concluded, "that the MD that said that those people that had cancer and was cured by Hoxsey didn't have cancer in the first place so the MD doctors were liers [sic]." trial proved that physicians (who denied the existence of cancer in those cured by Hoxsey) were in fact liars.

Such suspicions of deception were echoed by many of Hoxsey's supporters. In their view, not only did physicians obscure the nature of cancer, not only did they distort what was known about the disease and the effectiveness of interventions against it, but they did so intentionally. "Now you know as well as I do," wrote one critic, "that . . propaganda as saying the Hoxsey treatment is false is just as big a lie [as when] you claim healing for cancer by other treatments is the only way." "111 "The

I08. CT [McBride, Missouri] to G. P. Larrick, 23 February I957, Accession 63A292, Box 529, Folder 48, FDA archives.

I09. An alternative reading of this quotation is that, according to the letter writer, physicians claimed that patients who were treated by orthodox physicians (MDs) had cancer, while those who turned to Hoxsey did not. This reading captures the writer's concerns about physicians' denial that Hoxsey could successfully treat cancer but not the concern about the harmful effects of radiotherapy and surgery.

I Io. CT [McBride, Missouri] to G. P. Larrick, 23 February I957, Accession 63A292, Box 529, Folder 48, FDA archives.

I I I. HSH [Nielsville, Minnesota] to K. L. Milstead, 5 July 1956, Accession 63A292, Box 525, Folder AF27-026 (W-C) 4, FDA archives. For this writer, the proof that "other treatments" were not the way was a series of family deaths from cancer that occurred after orthodox treatments.

Why didn't my cousin get well who died a year ago after two operations at Mayo Clinic ??????????

Why didn't my Aunt get well after having a breast removed in Grand Rapids, Michigan ???????????????

Why didn't my Uncle get well after a operations [sic] and the Doctor refused to tell what the illness was ?????????? Can you telll [sic] me ??????? Can you ????????? 
damn bulletin you issued was nothing but a damn lie," noted another, "You can't fool me with such lies as it contained." others elaborated the point: "What right have you to place your rotten lieing $[s i c]$ filthy smear propaganda literature [in Post Offices]?";13 the "lies, deceit and published corruption ... [of]. . . a cruel, corrupt Mr George P. Larrick"; 114 "Department of Lies.,"115

Concerns about lies and deceit allowed Hoxsey's supporters to associate medicine and government with other groups that allegedly also lied to promote their own interests and agendas - the lies of the "communist," and sometimes the "Jew" and the "Catholic," often seen as subverting such institutions for their own purposes, as did that other inveterate liar: big business. But if medicine and government were subverted by such lying groups, they were also corrupted by something even darker, the ultimate cause of all their deceit-Satan himself. "Your smear attacks on Dr Hoxsey are the Vilest lies Ive [sic] ever read," wrote a correspondent from Council Bluffs, Iowa. "My Bible tells me that Satan is the father of all lies, and that God hates liars[.] It also tells me that no liar shall enter the kingdom of heaven ... My advice to you is for you to get right with God \& your fellow men. Eternity is a long long time to be sorry." 117 And another commentator warned the FDA that "God made the truth, the devil specializes in lies. How much better it will be, to be on God's side than on the side of old Satan."

The belief that lies and deceit might have satanic origins could bring out evangelistic impulses. ("Are you saved?" one asked the FDA. ${ }^{119}$ ) Repeatedly writers mixed an appeal to the agency to turn

I I2. DM [Texarkana, Arkansas] to G. P. Larrick, 23 February 1957, Accession 63A292, Box 529, Folder 49, FDA archives.

I I3. Anonymous [Willmar, Minnesota] to FDA, n.d., probably April I957, Accession 63A292, Box 529, Folder 54, FDA archives.

I I 4. WNP [Richmond, Virginia] to "His Excellency The President of the U.S.," Io July I956, Accession 63A292, Box 526, Folder I2, FDA archives.

I I 5 . Anonymous [notes written over an FDA leaflet, "Facts Regarding the Hoxsey Cancer Treatment”], n.d., 5, Accession 63A292, Box 526, Folder I2, FDA archives.

I I6. For suggestions that Jews-Jewish physicians?-feared Hoxsey, see CB [Cadillac, Michigan] to K. L. Milstead, I8 February I957, Accession 63A292, Box 529, Folder 47, FDA archives.

I 17. MMH [Council Bluffs, Iowa] to G. P. Larrick, 23 February 1957, Accession 63A292, Box 529, Folder 49, FDA archives.

I I8. CLR [Georgetown, Delaware] to George Larrick, 26 January I957, Accession 63A292, Box 528, Folder 43, FDA archives.

II9. IE [Ray, Minnesota] to FDA, I9 February I957, Accession 63A292, Box 529, Folder 49, FDA archives. 
to Jesus with the righteous desire for the eternal punishment for those who persisted in their persecution of Hoxsey. One correspondent, for example, urged George Larrick and the AMA to fall on their knees and to ask God for forgiveness, noting, as she put it, that "When Jesus comes back to earth and I hope that will be soon-the Drs of Medical Association will suffer for the crimes they have done."120 Another noted that he would be glad to hear that "you have turned from your wicked ways and accepted Christ as your own personal Savour [sic] before ia [sic] too late." 121 No doubt, such warnings of eternal damnation could serve to encourage people to turn to Jesus. Occasionally, however, the impulse to bring someone to Jesus was in danger of being overwhelmed by the desire for hellfire and damnation that awaited the critics of Hoxsey. As the writer from McBride, Missouri, noted: "I hope God will see that the TRUTH comes out soon and those who are Lieing [sic] will see HELL in full fire."122

If concerns about lies and deceit allowed Hoxsey's supporters to associate medicine and government with deceitful social and supernatural agencies, it also allowed them to differentiate Hoxsey and his supporters from such agencies. Correspondents constantly noted the lies and deceit of medicine and government as a means of contrasting these agencies with the "integrity," "good reputation," or "honesty" of Hoxsey and those who spoke for him, and so of asserting the authority and veracity of the latter. Thus one letter noted the writer's reliance on the statement of "a reputable buissness [sic] man known world wide for his veracity." "123 Another noted that Hoxsey had been investigated by "people of integrity," 124 that his treatment could be proven to the satisfaction of "those who are Just,"125 and that he "was sorry for those poor people who once had cancer were cured and lived to prove the merit of this method of cure[, only] to be branded as untruthful."126

I 20. FH [Fort Davis, Texas] to G. P. Larrick, 30 July I956, Accession 63A292, Box 526, Folder I3, FDA archives.

I2 I. TM [Pittsburgh, Pennsylvania] to George P. Larrick, Io September I957, Accession 63A292, Box 529, Folder 5I, FDA archives.

I22. CT [McBride, Missouri] to G. P. Larrick, 23 February I957, Accession 63A292, Box 529, Folder 48, FDA archives.

I23. CWJ [South Bend, Indiana] to FDA, 2 April I957, Accession 63A292, Box 529, Folder 53, FDA archives.

I24. RS [Bell Buckle, Tennessee] to Senator Albert Gore, i I February 1957, Accession 63A292, Box 529, Folder 50, FDA archives.

I25. Ibid.

I26. Ibid. 


\section{Journal of the History of Medicine : Vol. 61, July 2006}

The last quotation highlights a second reason for differentiating medicine and government from Hoxsey and his supporters. In the view of the latter, medicine and government routinely questioned their honesty and integrity. They were the subject of smear and innuendo by medicine and its allies. As one anonymous writer from Willmar, Minnesota, commented: "The God-fearing Public is beginning to be fed up with your line of propaganda of character smear and down-right lies." 127 Others enlarged on the point: "quit using the taxpayers['] money to call them [Hoxsey's patients] liars"; ${ }^{128}$ "Why do you folks [the FDA] make every body and every one out liars? Who is the liars?"129 Hoxsey's patients were not liars, claimed Hoxsey's supporters. On the contrary, they were people who spoke plainly, whose words (contrary to the alleged claims of orthodox physicians) were truthful and reflected what they really believed. Their language, supporters claimed, was true to the plain, honest soul within, just as the language of medicine and government was true to the corrupt souls within those institutions.

\section{Knowledge}

Such lies and deceit created a problem for Hoxsey's supporters. How were they to explain how they knew what was hopeful and what was not? Perhaps the dominant approach was to rely on what might be called an empiricist epistemology that saw proof of hope as based on the direct observation of a "cure." People routinely argued that they had hope in Hoxsey because they had observed him cure people in the past and consequently believed that he offered hope for others. Grounded in older vernacular traditions that saw the body as a sort of open book, available for all to read, and that judged efficacy in terms of the physical effects produced by a treatment on the patient's body, such an epistemology provided a valuable means

I27. Anonymous [Willmar, Minnesota] to FDA, n.d., probably April 1957, Accession 63A292, Box 529, Folder 54, FDA archives.

I28. CB [Cadillac, Michigan] to K. L. Milstead, I8 February I957, Accession 63A292, Box 529, Folder 47, FDA archives.

I29. RE [Waldron, Arkansas] to A. S. Goldhammer, I3 April I957, Accession 63A292, Box 529, Folder 54, FDA archives. RE wrote several letters in support of Hoxsey. See for example her letters to the FDA, I4 and 26 January I957, Accession 63A292, Box 528, Folder 28, FDA archives, II August 1956, Accession 63A292, Box 526, Folder 17, FDA archives. 
of countering medical lies and deceit. ${ }^{130}$ From this perspective, medicine had no monopoly on medical knowledge. Anyone could verify the disappearance of a tumor. Anyone could see the return of weight, appetite, and a healthy complexion. Thus, direct observation provided an assurance of authenticity in a world threatened by conspiracy and lies. It promised to expose the falsehoods that critics believed were promulgated by the medical profession and its supporters.

Physicians complained that most people were not competent to decide on whether a cure had taken place. Such "cures," they claimed, were often little more than the natural remission of a cancer that might return later with deadly results. They also argued that many so-called cancers were not cancers at all, but some other growths that Hoxsey's escharotic ate away or that disappeared of their own accord. But such arguments held little sway among those who wrote in support of Hoxsey. They observed friends and relatives disappear off to Dallas and return without the tumors that took them there. They described their own cures, how they took Hoxsey's medicine, and that the results were amazing. ${ }^{131}$ Growths disappeared, and people regained appetite, weight, or a healthy complexion, all of which showed that Hoxsey was doing what he claimed. As one correspondent put it, "the proof is plainly evident that the Hoxsey clinic is curing cancer." 132

Empiricism was neatly suited to the political concerns of many critics of medicine and government. To those who worried about antidemocratic tendencies in medicine and government, it provided a foundation - the experiences of ordinary men and women-upon which to validate a broader range of opinion than medicine or government allowed. To those who worried about medical attempts to define citizenship in terms of allegiance to official programs of cancer control, it provided a foundation upon which to base an alternative

I30. Charles E. Rosenberg, "The Therapeutic Revolution: Medicine, Meaning, and Social Change in Nineteenth-Century America," in Explaining Epidemics and Other Studies in the History of Medicine, ed. Charles E. Rosenberg (Cambridge: Cambridge University Press, I992), 9-3I, especially i 5.

I3I. EA [Regent, North Dakota] to FDA, I5 July I956, Accession 63A292, Box 526, Folder I2, FDA archives. MRC [Beulah Heights, Kentucky] to FDA, 27 February I957, Accession 63A292, Box 529, Folder 50, FDA archives. DBC [Everett, Washington] to President Eisenhower, 27 February 1957, Accession 63A292, Box 529, Folder 51, FDA archives.

I32. CHJ [Los Angeles, California] to K. L. Milstead, 25 July I956, Accession 63A292, Box 526, Folder I4, FDA archives. 


\section{Journal of the History of Medicine : Vol. 61, July 2006}

vision of citizenship. To those who worried about attempts to restrict consumer choice, it provided a basis upon which those who saw themselves as ordinary men and women could make such a choice. Empiricism was also well fitted to an attack on the conspiracies of communists, Catholics, and Jews, for it grounded the revelation of such conspiracies in the observations of those who saw themselves as ordinary Americans. It also had remarkable parallels with evangelical beliefs about conversion and holy living. By demanding visible evidence of a cure, empiricism argued for a similar kind of proof to that required by evangelical Protestants to demonstrate the genuineness of faith: visible evidence of conversion. Indeed, the language of empiricism often echoed that of evangelicalism. Many described their observations in terms of their "personal experience" or "witness" of a cure. ${ }^{133}$ Just as some evangelical Christians prized "personal experience" and "witness" over theological expertise, so it seems that many of those who wrote to the FDA prized personal experience and witness over medical or scientific expertise. $^{134}$

None of this is to say that people saw no limits to a faith in direct observation. Writers, for example, recognized that perceptions of a cure might be conjured out of an excess of hope, or that they might be the work of the devil. They also recognized that the fact of a cure could be a technically difficult thing to determine, and that the fact that the Hoxsey cure worked on one individual did not mean that it would work on another. However, in the heated debates over Hoxsey's treatments, such recognition had to be carefully handled. For example, Hoxsey's supporters feared that physicians used the tricks that hope could play on perception to undermine the validity of what

I33. One writer, for example, noted that he "personally witnessed Mr. Whitehead from Colorado. . . . [described as "hopeless" by the "leading doctor of Portland"]. . . . In six weeks he went home with only a healthy looking skin where the cancer had been." HS [St. Helena, California] to G. P. Larrick, 5 July I956, Accession 63A292, Box 525, Folder AF27-026 (W-C) 4, FDA archives. In some letters, "witness" referred not only to the activity of observing, but also to testimony to what was observed. Neither form of "witness" was given credibility by orthodox medicine.

I34. Although Hoxsey attracted considerable support from evangelicals, he also gained the trust of individuals from other religious groups such as Catholics and Episcopalians with different visions of theological expertise. Moreover, evangelicals themselves disagreed about whether the Bible said that the Christians had to have theological experts, preachers, or even a church. Some, such as the Plymouth Brethren, had assemblies with no regular paid preachers, while others accorded preachers a more important role in interpreting the word of God and in inspiring a congregation. 
many people saw, and so to restrict consumer choice. "I have seen the proof [a writer from Northfield, Michigan wrote, defending his observation with the following comment]. Not because I am a fanatic grasping at straws or what ever quackery product might offer the threads of hope." 135

Faced with such problems, Hoxsey's supporters sought to bolster their observations with other forms of evidence. Some confirmed their own observations of a cure with the observation of an orthodox physician. Others told the FDA of the cures they had heard of from trusted friends, family, colleagues, and pastors. ${ }^{136}$ They also wrote of cures reported in magazine articles, in tracts, on the radio, in sermons, and in meetings organized by Hoxsey and his followers. They visited Dallas and Portage, "talked to many cured folks there," 137 and informed the FDA and other organizations of their findings. "I went to hear Dr. Hoxsey [one correspondent wrote the FDA] and listen to testimonies from people who went to him when orthodox medical men had given them up as hopeless, and at the Hoxsey Clinic they were restored to health."138 "Five of my own family went to Dallas to investigate the Hoxsey Cancer Clinic," one correspondent wrote to J. Edgar Hoover, Chief of the FBI, highlighting the inspirational value of such talk. "We spent two days at the clinic talking to patients and Drs. and those patients are the most cheerfull [sic] people I have ever met. Being lifted from the depths of despair and gloom of certain death to hope and faith you could not believe without seeing." 139

Such comments highlight two other means by which people sought to support their arguments in favor of Hoxsey. First, since

I35. EJS [Northville, Michigan] to J. L. Harvey, 29 January 1957, Accession 63A292, Box 528, Folder 29, FDA archives.

I36. One woman, for example, noted that that she had heard of a child who went to Dallas "as a last hope and he is cured." JN [Crete, Nebraska] to FDA, 2 I July I956, Accession 63A292, Box 526, Folder I2, FDA archives. Another commented that several ministers had traveled to Dallas to validate the cure. MB [Smith, Nevada] to G. P. Larrick, I 8 February I957, Accession 63A292, Box 529, Folder 49, FDA archives.

I37. EM [Caldwell, Idaho] to President Eisenhower, 27 February 1957, Accession 63A292, Box 529, Folder 5I, FDA archives.

I38. RRK [Chicago, Illinois] to FDA, 6 February 1957, Accession 63A292, Box 529, Folder 47, FDA archives.

I39. MDA [Manti, Utah] to J. Edgar Hoover, 26 June I956, Accession 63A292, Box 525, Folder AF27-026 (W-C) 7, FDA archives. This correspondent wanted Hoover to recommend a grand jury investigation of the FDA over its treatment of Hoxsey. The FBI forwarded this letter to the FDA, 6 July 1956. 


\section{Journal of the History of Medicine : Vol. 61, July 2006}

many relied on the opinions of others obtained through "talk" and "reading," epistemological questions were (as previously mentioned) often tied up with assessments of individual integrity, reputation, and honesty. According to this rationale, the credibility of such opinions could not be assessed without knowledge of those who provided them. Their association with someone of honesty or integrity was a path toward authentication. Second, many also relied on a sort of testing or evaluation of evidence or opinions. In their search for a cure, some noted that they sought second opinions from physicians, friends, family, and others, or that they evaluated medical opinions of Hoxsey by the effects of his treatment. Recall the hapless physician who, having previously diagnosed the patient as hopeless, now found him or her returned from Dallas and cured of the disease; or the many people who underwent surgery or radiotherapy to no effect, only to be cured by Hoxsey; or those who were told that the Hoxsey treatment was not a cure, only to hear of friends who had been cured by the healer; or those who turned to prayer and Bible reading after hearing conflicting accounts of Hoxsey. All these methods could be used to evaluate empirical observations, just as empirical observations tested the value of such methods. Thus the value of personal observation of a "cure" was, like hope itself, often assessed in relational terms. Its significance was often determined only in relation to other methods of assessment. Personal observation was assessed against the opinions of others and against the actual results of treatment.

If empiricism was suited to the political concerns of many critics of medicine and government, so was an alternative epistemological rationale for assessing the hopefulness or otherwise of a cure: a fundamentalist tendency among some writers to elevate correct belief and doctrinal exactitude over experiential claims. From this perspective, there was only one truth and one epistemic tool: the Bible. Those who sought truth elsewhere were wrong, whatever they might claim among themselves. They were ultimately deceptive and evil and doomed to divine condemnation. Such attitudes left little room for any type of cooperation. Compromise was a vice, not a virtue. The world was fallen, and government institutions were evil, unless and until the Lord led the righteous to establish a theocracy or came again. To most, there was no use in working to improve things; the Lord's second coming would see to that. In a fallen 
world, only a position of full and complete segregation from the larger society could provide the critical distance from which its condemnation could come. It was only when organizations such as the FDA imposed on their disengaged world that they were forced to engage. And in this case, they did so by asserting the reality and certainty of a hope based not so much on direct personal observation of a cure as on correct doctrinal belief. Fundamentalist tendencies among Hoxsey's supporters thus provided a challenge not only to medical knowledge but also to the vernacular empiricism that countered it. They stated that all knowledge based on human endeavor-medical or vernacularwas lacking in certainty compared with that based on God. In practice, however, many commentators seem to have mixed empirical and doctrinal approaches - for example, observing (witnessing?) a cure, and explaining their observations in terms of correct belief.

A final point needs to be made about Christian responsesfundamentalist or otherwise - to the official "message of hope." While many Christians tended to assess this message (as they also assessed their own observations) by means of prayer, Bible reading, and fellowship, they also tended to measure it against meanings of hope drawn from the Christian tradition. As one pastor noted, sending the FDA a leaflet containing a collection of Bible promises, the Bible "has never failed to bring peace, the assurance of forgiveness and blessed hope for the future here and hereafter to all who put their trust in Him." 140 The orthodox "message of hope" provided no such "blessed hope." It did not offer hope for the hereafter; it gave no hope of salvation, no spiritual sustenance, and it relied on the wisdom of men rather than the blood of the Lamb. It offered none of the certainties that Christ promised. "Would thinks and hopes satisfy you?" a tract sent by one correspondent asked, if on a dark night far from home you asked a passerby the way to town and he told you that he "thinks that such and such a way is the right one, and hopes you will be all right if you take it." The answer was no; according to the tract, the reader wanted (or should want) certainty, and in life that certainty came only through salvation. ${ }^{141}$

I40. JMA [Temple City, California] to FDA, 30 January I957, Accession 63A292, Box 529, Folder 47, FDA archives.

I4I. RWR [Melrose Park, Illinois] to G. P. Larrick, 9 February 1957, and George Cutting, Safety, Certainty and Enjoyment (The American Edition, Chicago: Good News Publishers, n.d.), 4, Accession 63A292, Box 529, Folder 47, FDA archives. 


\section{Doubts}

Although the FDA received many letters from supporters of Hoxsey, it also received a smaller number from others who had doubts about the healer. Thus, one woman worried about her mother's continued faith in Hoxsey despite the fact that he seemed to be doing nothing for her; ${ }^{142}$ another about a father who denied himself necessities to support Winrod; ${ }^{143}$ another about a father taking a huge assortment of Hoxsey's pills "in the hope it will cure him"; ${ }^{144}$ another that a brother's interest in Hoxsey might "undo all the doctors have done." 145 As such comments suggest, many had particular worries about family members who had become involved with Hoxsey, his supporters, or other alternative practitioners. The point was made by a man from Iron Mountain, Michigan, concerned about his wife. Despite hearing the truth of her condition ("No hope, and only a matter of time" ${ }^{146}$ ), and despite losing her earlier faith in Hoxsey, she had, he claimed, continued to seek help from other cancer curers. "Desperation [he reflected] causes a panic, and all persons close to the one afflicted look for hope, anywhere."147

This is not to say that every doubter was opposed to vesting hopes in Hoxsey. It has already been noted that some may have welcomed the comfort it brought to people who otherwise had no hope. Even doubters could find it difficult to deny the dying, those classed as "hopeless" by their physicians, the consolation that hope in Hoxsey might provide. Nevertheless, there were limits to this acceptance of the psychological benefits of Hoxsey's treatment. As the quotations above suggest, some worried that the hopes vested in Hoxsey might work against the benefits offered by other more orthodox treatments, undoing all the doctors had done, as one put it. Others may

I42. JE [Okmulgee, Oklahoma] to FDA, 3 I July I956, Accession 63A292, Box 526, Folder I5, FDA archives.

I43. RA [Pittsburg, Kansas] to FDA, 8 February 1956, Accession 63A292, Box 529, Folder 47, FDA archives.

I44. FS [Rock Rapids, Iowa] to FDA, 27 June 1956, Accession 63A292, Box 525, Folder AF27-026 WC (6), FDA archives.

I45. SMW [Carmichael, California] to FDA, 8 February 1957, Accession 63A292, Box 528, Folder 3I, FDA archives.

I46. FGR [Iron Mountain, Michigan] to Walter Witchell, American Broadcasting System, [NY], n.d., probably i953, Accession 63A292, Box 525, Folder AF27-026 (5), FDA archives.

I 47. Ibid. His wife was still living, "if you could call it that, but I know that soon, the end will come." 
have worried about the emotional motivations behind hope-even among those for whom medicine could do nothing. The man from Iron Mountain makes the point again. His comment was about the desperation and panic that prompted the search for hope. Among the psychological benefits of hope were the calm and consolation it could provide and perhaps the sense of doing something about an impossible situation. The terms "desperation" and "panic" suggest not only a disturbing lack of consolation and calmness, but also a loss of control.

Such anxieties highlight the Janus-faced nature of hope for some individuals. Most writers accepted that hope could be immensely valuable to people with cancer. It helped to sustain them through what could be long, painful, and uncertain courses of treatment. It could be a comfort, as much to those who might be curable as to the dying. And it could be a consolation to their families and friends. Yet it also raised a number of worries. To what extent did hope blind one to other, perhaps more effective, treatments? And what was one to do when the comfort and consolation that hope offered disappeared, and desperation and panic set in? Hope seemed disturbingly powerful. It was able to paralyze an individual as much as to stimulate him or her to action; able to make someone change course erratically as much as it might sustain them through difficult times; able to agitate a person as much as to soothe them. It could be a sign of an individual's attempt to come to grips with a difficult condition, but it could equally be a sign that they had lost control. Hope could help them to master (or at least to cope with) a difficult situation, but hope could equally master them.

For such reasons many of those who wrote to the FDA were concerned to monitor and manage their own hopes and those of others. They worried about how one decided on what was a true hope and what was false. They worried about the extent to which one could trust a diagnosis of hopelessness or the promise of hope. Did orthodox physicians really know enough about cancer to make such a judgment? Did Hoxsey know enough to offer hope? To what extent did commercial or professional interests influence the judgment of enthusiasts for any particular treatment or approach, orthodox or otherwise? Did such interests also encourage people to denigrate competing techniques or approaches? Was it possible that hidden conspiracies within government or medicine were working to 
undermine hope? Such issues could be complicated by the tendency of hope to blind and master. To what extent were the answers to these questions influenced by one's own hopes and desires? How did one know? And was it possible to escape the delusions that hope might promise? All these questions were addressed by individuals seeking to make sense of the various messages of hope they received about cancer, and it is likely that they came to different conclusions at different times. Even those who, when they wrote to the FDA, had come to a conclusion as to the validity of the hopes offered by Hoxsey, acknowledged that they had formerly held different positions. Some who started with hope in orthodox medicine turned to Hoxsey. Likewise, former Hoxsey supporters found their hopes in him unfulfilled and turned toward orthodox medicine.

If hope was something to be monitored and managed, it also provided a means of talking about other concerns. We have already noted the anxieties expressed by Hoxsey's supporters about social, economic, and (evil) supernatural forces at work to discredit Dallas and Portage. But Hoxsey's doubters also worried about such issues, though they came to different conclusions. If Hoxsey's supporters worried about the commercial imperatives behind orthodox medicine's claims to cure cancer, his critics-while not necessarily discounting such claims - also saw similar forces at work behind the Hoxsey cure. One writer-a medical technician-wanted "some good, wholesome, all-American statistics to satisfy the "fake followers' that this clinic is nothing but a money making machine."148 Likewise, they also worried about the cost of treatment. Some were concerned that Hoxsey was financially exploiting vulnerable and often not-wealthy people. But most - critics and supporters of Hoxsey alike-were also concerned about the cost of orthodox treatment. ${ }^{149}$

Critics of Hoxsey were much less likely to see government as the enemy. It was rarely corrupt, nor was the medical profession apparently always after its fee, or its lawyers so full of twisted words. Indeed, it is noticeable that correspondents who were critical of

I48. EN [McPherson, Kansas] to FDA, 22 January I957, Accession 63A292, Box 528, Folder 43, FDA archives.

I49. In one letter, for example, a man from Carson City (fearful of Hoxsey) asked for help in finding free treatment for a brother-in-law with a tumor on the brain. LCH [Carson City, Nevada] to FDA, I6 February I957, Accession 63A292, Box 529, Folder 48, FDA archives. 
Hoxsey could feel impelled to note the integrity of the medical profession. ${ }^{150}$ Many echoed medical concerns and language about Hoxsey's claims. Some worried, as one correspondent put it, about the "pretty fantastic claims for the treatment and have wondered about the reliability of such claims ... [including] [r]ather miraculous cures [that] have been claimed for 'hopeless' cases." ${ }^{151}$ Others wrote of the "false hopes" 152 raised by articles such as that in Man's Magazine, mentioned earlier in this article, and (perhaps to the dismay of the critics of the FDA) argued that it was "the function of government to do whatever is necessary to safeguard the welfare of the people." 153 And we have already noted their anxieties about allegations that Hoxsey might be exploiting people's emotional vulnerability.

Nevertheless, there was still some questioning of government. Just because they doubted Hoxsey did not mean that they entirely trusted government or medicine. Some were puzzled as to why the government had not taken stronger action against Hoxsey. As one correspondent asked, "why is he allowed to continue and give false hopes to thousands of people if his method or system has no merit . . . why does the government allow Hoxsey, even help him spread, as mentioned above, false hopes among the population?"154 And another who lost a husband to cancer after he attended the Hoxsey Clinic asked a related question: "So if the government or anyone else has proof that tons of those pills are useless why dont [sic] they close them up and save alot [sic] of victims alot [sic] of expense and high hopes[?]"155 As such comments suggest, many saw government as conspiring - at least by default - in promoting the false or high hopes that Hoxsey offered. The forces that doubters saw behind such "conspiracy" are not, however, very clear from these letters,

I50. RMS [Grand Rapids, Michigan] to FDA, 8 March I957, Accession 63A292, Box 529, Folder 5I, FDA archives. RMS's brother had visited the Hoxsey Clinic, which diagnosed him as having cancer. When he died, an autopsy, RMS noted, revealed no cancer.

I5I. ENE [Harrisonburg, Virginia] to FDA, I3 July 1956, Accession 63A292, Box 525, Folder AF27-026 (W-C) 9, FDA archives.

I 52. AJK [Allentown, Pennsylvania] to FDA, i I July I953, Accession 63A292, Box 525 , Folder AF27-026 (5), FDA archives.

I 53. AJK [Allentown, Pennsylvania] to FDA, 5 August 1953, Accession 63A292, Box 525, Folder AF27-026 (5), FDA archives.

I 54. HM [San Francisco, California] to FDA, I March 1957, Accession 63A292, Box 529, Folder 50, FDA archives.

I 55. VH [Chicago, Illinois] to FDA, 9 August 1956, Accession 63A292, Box 526, Folder I6, FDA archives. 


\section{Journal of the History of Medicine : Vol. 61, July 2006}

though it is likely that some may have shared with Hoxsey's supporters a fear that commercial interests might be working to corrupt government.

Supporters and doubters alike thus worried, albeit for different reasons and with different emphasis, about the role of government and commercialism in medicine. They also worried about the role of supernatural forces. It should be said that doubters were much less likely to express religious convictions than those who wrote in support of Hoxsey, and there is very little of the language of hell and damnation that characterized the letters previously referred to. Nor, it should be said, did many doubters write of lying as the work of the devil. Nevertheless, the supernatural intruded into their accounts. A number saw the workings of the divine in the therapeutic choices they made (one, for example, cited "Divine Providence" ${ }^{156}$ for her decision to visit an orthodox surgeon rather than Hoxsey). Others turned to prayer, both for those who suffered, and for medicine and research. As one correspondent with a family member with cancer noted: "We hope and pray that a cure can be found." 157

Two final comments need to be made. The first concerns how Hoxsey doubters knew what was hopeful or hopeless. It should be said that, like supporters, many doubters emphasized the importance of observation, testing, and assessments of integrity in their decisions, sometimes described as "witness," "experience," or "testimony." Like Hoxsey's supporters, doubters visited the clinics in Dallas and Portage, observed (apparent?) cures, listened to the testimony of others, and even tested Hoxsey by seeking a second diagnosis. ${ }^{158}$ But whereas Hoxsey's supporters wrote to inform the FDA of the wonders of Dallas and Portage, his doubters often came away with a different impression. Direct observation could work as much against Hoxsey as it could work for him. Visitors to his clinics could come away as disillusioned as others were inspired. Doubters worried about his sales techniques, the quality of his staff, and the nature of his therapy.

I 56. GAW [Lakeland, Florida] to FDA, I 8 February I957, Accession 63A292, Box 529, Folder 49, FDA archives.

I 57. AR [Flushing, New York] to U.S. Government Medical Department, I I February I957, Accession 63A292, Box 529, Folder 47, FDA archives.

I58. See J. L. Griggs to Oliver Field, I4 December I953, Box 0367, File 04, Health Fraud Collection, AMA archives. 
But the fact that they had traveled to Dallas or Portage to obtain this impression highlights the importance that they attached to their own observations in coming to an assessment of the value of Hoxsey's claims. Indeed, there is evidence to suggest that some visited orthodox clinics for precisely the same reason. Although the FDA was keen to undermine such observations when they were cited in support of Hoxsey, they were generally less keen to deny them when they were used in support of Rochester or Bethesda.

The second comment concerns the relationship between Hoxsey and evangelical and fundamentalist Protestantism. The dominance of such Christians among his supporters should not be taken to mean that they did not have their doubts about him. One correspondent, for example, was perturbed about an "absurd" advertisement for Hoxsey's book; a particularly disturbing event, since it appeared in a magazine that only accepted "Bible truths," and he knew the editor, and asked the AMA for advice. ${ }^{159}$ (Is this an indication that fundamentalist beliefs in doctrinal exactitude and correct belief could be turned against Hoxsey?) Another correspondent noted his belief in miracles, yet saw Hoxsey as a charlatan. ${ }^{160}$ Writing at a time of a revival in faith healing ${ }^{161}$ (with which Hoxsey sometimes associated himself), this writer included Hoxsey in a list of frauds, rascals, and pretenders that included Gerald Winrod, "Oral Roberts, A. A. Allen and their like." 162 Faith healing may have been acceptable to many Pentecostalists. But it could be the work of the devil to other denominations or faith traditions. This writer, for example, contrasted the above "frauds" with the evangelical preacher Billy Graham, who "has very little or nothing to say about miraculous healings." 163 So it was that Hoxsey's association with faith healing reveals the importance of denomination and religious tradition in inspiring support and doubts about his claims.

I59. H. T. Mydland to AMA, i I May I957, Box 0369, File 05, Health Fraud Collection, AMA archives.

I60. John J. Johnson to FDA, 23 May I957, Box 0369, File 05, Health Fraud Collection, AMA archives.

I6I. David Edwin Harrell, Jr., All Things Are Possible: The Healing and Charismatic Revivals in Modern America (Bloomington: Indiana University Press, I975), 25-I 49.

I62. John J. Johnson to FDA, 23 May I957, Box 0369, File 05, Health Fraud Collection, AMA archives.

I63. Ibid. 


\section{Agreements That Divide}

It is clear from the above that hope had a complex set of meanings for Americans in the mid-twentieth century. These meanings emerged from an engagement with cancer experts' "message of hope," but also the messages put out by many others-by their physicians and pastors, by their friends and family, as well as by the media and by alternative practitioners such as Hoxsey. Men and women interpreted these messages in the light of their experiences of cancer, and through their social, political, religious, and economic beliefs and interests. Meaning, in other words, was constructed from many different sources as people sought to articulate what they meant by hope and why they supported one side or the other. While the bulk of evidence in this article comes from those who favored Hoxsey, other evidence suggests that they shared much with those who had their doubts about the healer. On both sides of the debate, people saw cancer as curable; agreed that quackery was anathema; and saw a role for personal experience and witness in deciding on a cure. Yet they also disagreed on who offered the best hope of a cure, who was the quack, and the extent to which personal experience and witness challenged scientific knowledge.

Other agreements divided supporters and doubters. Both used the term "hope" to refer to the existence of an "authentic" or "real" possibility, as when a disease, a case, or an individual was labeled "hopeful" or "hopeless," or when a particular healer or technique was labeled the "only hope" or as offering "false hopes." (However, supporters and doubters differed as to what constituted an authentically "hopeful" or "hopeless" case, what was a "true" or "false" hope.) Both also agreed that there existed (often hidden) agents, forces, and interests that worked to obscure the reality of a hope. These agents, interests, and forces might be psychological, as when people worried that emotions-hope among them-might cloud their own judgment unbeknownst to themselves. They might be supernatural, as when the devil or his agents were said to promote false hopes. They might also be economic, political, or social, as when industrial, communistic, and medical interests were said to be working within government to undermine faith in Hoxsey, or Hoxsey was said to exploit for commercial reasons the hopes and fears of people with cancer. Whatever the nature of the hidden force-be it 
psychological, supernatural, commercial, political, or social-it could be a danger to real hopes (the actual chance of a cure), though people differed as to when such agents, interests, or forces were at work and what the outcome was.

If both supporters and doubters used the term "hope" to refer to the existence of an authentic possibility, they also used it to refer to an emotional or psychological force: a sense of expectation, a desire, a yearning. Few appear to have disputed that such an emotional or mental attitude was itself desirable. It could be a stimulus to knowledge and effective care. It could be a comfort, and it might even help in the healing process. Yet it was a difficult thing to handle, and in two different ways. ${ }^{164}$ On the one hand, a deficit of hope-hopelessness-could undermine any attempt at healing, blinding people to the reality of the hope (the possibility of a cure) on offer. On the other hand, an excess of hope could also blind and mislead. Hope-the emotionwas thus something that had constantly to be monitored and managed. Yet supporters and doubters of Hoxsey found that people responded to hope in quite unpredictable ways, and some could despair of ever being able to manage their own hopes or those of others. Part of the reason for this was, commentators argued, that people's hopes were easily manipulated by others-be they supernatural beings, commercial interests, or political groups, all of which employed hope to promote their interests, agendas, and influence.

The knowledge that hope could be used to manipulate people allowed letter writers to talk about the social world of cancer. Supporters and doubters of Hoxsey divided this world into two opposed pairs. The first pair included, on the one hand, those who were able to control or manage their hopes (and perhaps also manage the hidden forces behind them), and those, on the other hand, who were unable to control or manage them. However, supporters and doubters tended to differ as to who fit in each category, as they also differed over who fit in the other pair. This second pair was divided into those who manipulated hope for their own purposes, and those who sought to employ it for the good of others. To Hoxsey's supporters, Hoxsey tended to fall into the second category. Not only

I64. For parallel concerns about the difficulties of handling emotion, see David Cantor, "Representing 'The Public': Medicine, Charity and Emotion in Twentieth-Century Britain," in Steve Sturdy, ed., Medicine, Health and the Public Sphere in Britain, 1600-2000 (London and New York: Routledge, 2002), I45-68. 
did he offer a "real" hope, he also employed "hope" as a psychological force for the benefit of others. By contrast, Hoxsey's supporters tended to suggest, not only did medicine, science, industry, and government offer doubtful hopes of a cure, they also manipulated people's hopes for their own economic, political, and social purposes, rather than for the benefit of people with cancer. Hoxsey's opponents disagreed with such an analysis. Doubters tended to see Hoxsey as the manipulator and were less likely to write about regular physicians and scientists manipulating hopes for their own purposes.

Critics and supporters of Hoxsey thus shared certain cultural assumptions about hope. Both distinguished between "real" and "false" hopes; both saw hope as a powerful emotional or psychological force that could (in excess or deficiency) undermine knowledge of what was true or false, and consequently also undermine efforts to cure the disease; and both distinguished between (on the one hand) those who were vulnerable to hope and those who were able to control its urges, and (on the other hand) between those who used hope to manipulate or to help. But shared cultural assumptions did not imply agreement as to what constituted "real" or "false," or "excessive" or "deficient" hope; how such hopes might be evaluated; or who was to be classed as vulnerable, manipulative, or helping. Nor, by extension, did shared assumptions imply agreement over what was wrong with approaches to cancer or where things needed to change. In writing about hope, individuals articulated a range of sometimes conflicting social, cultural, political, economic, and religious beliefs that helped them set out their position on Hoxsey and the FDA's campaign against him. In doing so, they also articulated social and cultural identities and values that went beyond the struggle between Hoxsey and his opponents. 